\title{
(2) OPEN ACCESS \\ Genetic burden linked to founder effects in Saguenay-Lac-Saint-Jean illustrates the importance of genetic screening test availability
}

\author{
Mbarka Bchetnia, 1,2 Luigi Bouchard, ${ }^{3,4}$ Jean Mathieu, 4,5 Philippe M Campeau (D) , \\ Charles Morin, ${ }^{2,4}$ Diane Brisson, ${ }^{7}$ Anne-Marie Laberge, ${ }^{6}$ Hélène Vézina, ${ }^{2,8}$ \\ Daniel Gaudet, ${ }^{7}$ Catherine Laprise (D) ${ }^{1,2}$
}

For numbered affiliations see end of article.

\section{Correspondence to}

Professor Catherine Laprise, Département des sciences fondamentales, Université du Québec à Chicoutimi, Chicoutimi, QC G7H 2B1, Canada;

catherine.laprise@uqac.ca

Received 25 February 2021 Revised 27 March 2021

Accepted 14 April 2021
D Check for updates

(C) Author(s) (or their employer(s)) 2021. Re-use permitted under CC BY-NC. No commercial re-use. See rights and permissions. Published by BMJ.

To cite: Bchetnia $M$,

Bouchard L, Mathieu J, et al. $J$ Med Genet Epub ahead of print: [please include Day

Month Year]. doi:10.1136/

jmedgenet-2021-107809

\section{ABSTRACT}

The Saguenay-Lac-Saint-Jean (SLSJ) region located in the province of Quebec was settled in the 19th century by pioneers issued from successive migration waves starting in France in the 17th century and continuing within Quebec until the beginning of the 20th century. The genetic structure of the SLSJ population is considered to be the product of a triple founder effect and is characterised by a higher prevalence of some rare genetic diseases. Several studies were performed to elucidate the historical, demographic and genetic background of current SLSJ inhabitants to assess the origins of these rare disorders and their distribution in the population. Thanks to the development of new sequencing technologies, the genes and the variants responsible for the most prevalent conditions were identified. Combined with other resources such as the BALSAC population database, identifying the causal genes and the pathogenic variants allowed to assess the impacts of some of these founder mutations on the population health and to design precision medicine public health strategies based on carrier testing. Furthermore, it stimulated the establishment of many public programmes.

We report here a review and an update of a subset of inherited disorders and founder mutations in the SLSJ region. Data were collected from published scientific sources. This work expands the knowledge about the current frequencies of these rare disorders, the frequencies of other rare genetic diseases in this population, the relevance of the carrier tests offered to the population, as well as the current available treatments and research about future therapeutic avenues for these inherited disorders.

\section{INTRODUCTION}

Located $200 \mathrm{~km}$ northeast of Quebec City, Canada, the Saguenay-Lac-Saint-Jean (SLSJ) region is a relatively geographically isolated region with approximately 279000 inhabitants (https://www.stat.gouv. qc.ca). The genetic structure of its population is considered to be the product of three successive migration waves corresponding to a triple founder effect (figure 1): (a) the first founder effect took place during the French regime (1608-1760) when approximately 10000 immigrants settled in the Saint Lawrence valley, in the west of the Province of Quebec. They account for the major part of the contemporary French-Canadian gene pool ${ }^{1}$; (b) the second founder effect started at the end of the 17th century, when inhabitants from Quebec city and Côte-de-Beaupré (on the north shore of the Saint Lawrence river) moved to the Charlevoix region where 600 individuals settled between 1675 and $1840^{2}$; (c) the third founder effect corresponds to the colonisation of the SLSJ region. It started in the 1830 's with the arrival of inhabitants coming first mostly from the nearby Charlevoix region, and afterwards from other regions of the Saint Lawrence valley. ${ }^{3}$ From 1838 to 1911, almost 30000 individuals migrated to the SLSJ, $70 \%$ of them from Charlevoix. ${ }^{45}$ Thus, SLSJ provides a great example of a founder population.

In the last decades, many studies have investigated rare genetic disorders or susceptibility genes showing higher frequency in the SLSJ population. Altogether, these studies indicate that hereditary disorders in this population follow a specific pattern consistent with a founder effect: the 'founder' diseases have a higher prevalence explained by a lower genetic variability whereas some others (eg, phenylketonuria) are ultra-rare or not reported in the SLSJ population. ${ }^{6-8}$ Also consistent with the characteristics of settlement history, many reports documented that most of the genetic disorders found in the SLSJ region are also found in Charlevoix. ${ }^{9}$ As the existing founder effect increases haplotype homozygosity and reduces genetic diversity, many geneticists and physicians worked on the SLSJ population for gene discovery as well as for clinical and epidemiological studies. ${ }^{10-13}$

From a research standpoint, the SLSJ population has also been of great interest to demographers and population geneticists. A research programme was developed in the 1980s through the use of the complete genealogy of the SLSJ population available in the BALSAC database (https://balsac. uqac.ca/). A major goal of these studies was to understand and explain the role of demographic dynamics and population history in the origin and spread of genetic diseases. Results have confirmed the impact of the founder effect and its associated factors, such as drift and remote inbreeding. These studies have also clearly established that, contrary to a widely held belief, consanguineous marriages were similar and even less frequent then in the other regions of the Province of Quebec. Consanguinity therefore cannot explain the observed higher frequency of rare genetic diseases in the SLSJ. ${ }^{6} 81415$ 


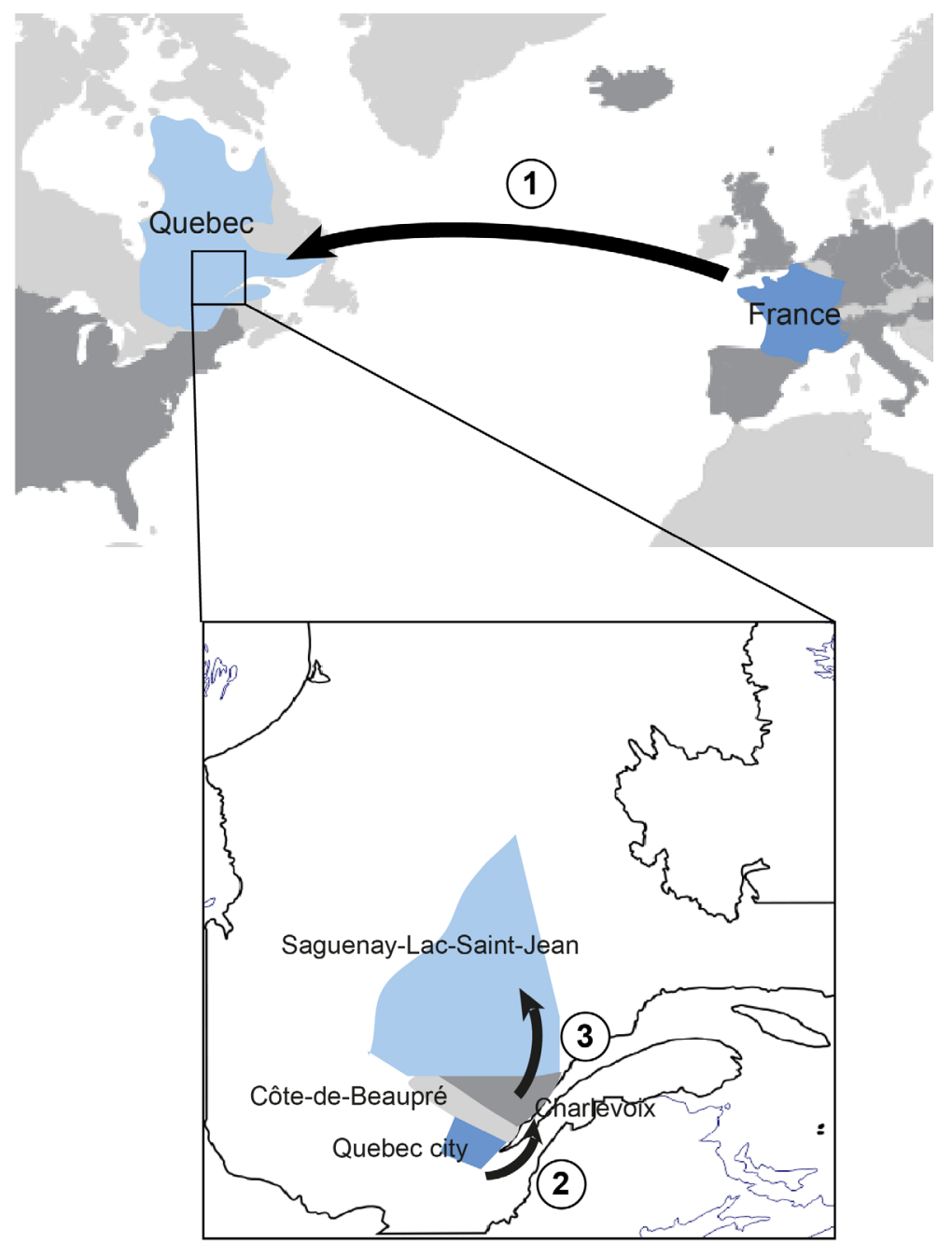

(1) First founder effect, (2) Second founder effect, (3) Third founder effect

Figure 1 Three main migratory events contributing to the founder effect in Saguenay-Lac-Saint-Jean (SLSJ) region. During the 17th and 18th centuries, between 10000 and 12000 immigrants, mainly from France, settled in the Saint Lawrence Valley (first founder effect). From the end of the 17th century, inhabitants of the Saint-Lawrence Valley, more particularly from Quebec City and the Côte-de-Beaupré area, settled in the Charlevoix region (second founder effect). Finally, settlers from Charlevoix moved to the SLSJ region from the 1830s (third founder effect). They were later followed by settlers from other Quebec regions, but they represent the majority of the founders of the SLSJ population.

A better understanding of the genetic characteristics of these diseases has made it possible to offer genetic counselling for affected patients and their families and free carrier testing screening for the Quebec people with at least one grandparent born in the SLSJ, Charlevoix or Côte-Nord regions (https:// www.sante.gouv.qc.ca/tests4maladies). Currently, the carrier test includes four selected diseases with increased incidence in SLSJ (autosomal recessive spastic ataxia of CharlevoixSaguenay (ARSACS | MIM 270550), agenesis of the corpus callosum with/without peripheral neuropathy (ACCPN I MIM 218000), Leigh syndrome French-Canadian type (LSFC | MIM 220111) and hereditary tyrosinemia type 1 (TYRSN1 | MIM 276700). ${ }^{16}$ The carrier frequency of these diseases is between $1 / 19$ and $1 / 23$ meaning that $20 \%$ of the SLSJ inhabitants carry the mutated allele of at least one pathogenic variants causal of these recessive diseases.

In this review, we present some of the most frequent hereditary diseases identified in SLSJ and published in the literature. PubMed, Google Scholar and other documentary sources were explored using the following key words: Saguenay-Lac-SaintJean (SLSJ), Charlevoix, French-Canadian origin, genetic disease, founder mutation and carrier test. When available, updated data are provided (table 1). We describe the estimated frequency, clinical and genetic characteristics, available or emerging treatments and potential impacts on public health of these diseases. Finally, we discuss the clinical utility and highlight some issues related to a recently developed multiplex recessive diseases carrier testing programme offered to couples originating from the SLSJ.

\section{Rare autosomal recessive diseases with higher prevalence in} Saguenay-Lac-Saint-Jean population

Autosomal recessive spastic ataxia of Charlevoix-Saguenay (ARSACS, MIM 270550)

Autosomal recessive spastic ataxia of Charlevoix-Saguenay is an early-onset neurodegenerative disorder due to progressive degeneration of the spinal cord and the cerebellum. ${ }^{17}$ ARSACS manifests between 12 and 18 months with earlyonset ataxia, and leads to peripheral neuropathy, spasticity, hypermyelination of the retinal nerve fibres, and finger and foot deformities. ${ }^{18}$ It was first described among a cohort of 
Table 1 Inherited disorders in Saguenay-Lac-Saint-Jean (SLSJ)

\begin{tabular}{|c|c|c|c|c|c|c|c|c|c|}
\hline Disease & OMIM & $\begin{array}{l}\text { Worldwide } \\
\text { frequency }\end{array}$ & Frequency in SLSJ & $\begin{array}{l}\text { Carrier } \\
\text { rate in } \\
\text { SLSJ }\end{array}$ & Gene & Founder mutations in SLSJ & $\begin{array}{l}\text { Founder } \\
\text { allele } \\
\text { frequency in } \\
\text { SLSJ }\end{array}$ & $\begin{array}{l}\text { Founder allele } \\
\text { frequency } \\
\text { (gnomAD)** }\end{array}$ & References \\
\hline \multirow{2}{*}{$\begin{array}{l}\text { Autosomal recessive spastic } \\
\text { ataxia of Charlevoix- } \\
\text { Saguenay (ARSACS) }\end{array}$} & \multirow[t]{2}{*}{270550} & \multirow[t]{2}{*}{ N/A } & \multirow[t]{2}{*}{$1 / 1932$} & \multirow[t]{2}{*}{$1 / 22$} & \multirow[t]{2}{*}{ SACS } & c.8844del (p.lle2949fs) & 0.926 & $610^{-5}$ & \multirow[t]{2}{*}{192528} \\
\hline & & & & & & - c.7504C>T (p.Arg2502X) & 0.037 & $10^{-5}$ & \\
\hline \multirow{2}{*}{$\begin{array}{l}\text { Agenesis of corpus callosum } \\
\text { and peripheral neuropathy } \\
\text { (ACCPN) }\end{array}$} & \multirow[t]{2}{*}{218000} & \multirow[t]{2}{*}{$\mathrm{N} / \mathrm{A}$} & \multirow[t]{2}{*}{$1 / 2117$} & \multirow[t]{2}{*}{$1 / 23$} & \multirow[t]{2}{*}{$S L C 12 A 6$} & $\begin{array}{l}\text { c.2436delG } \\
\text { (p.Thr813Profs) }\end{array}$ & 0.99 & $310^{-5}$ & \multirow[t]{2}{*}{3132} \\
\hline & & & & & & $\begin{array}{ll}\text { c.1584-1585delCTinsG } \\
\text { (Phe529fsX531) }\end{array}$ & $\mathrm{N} / \mathrm{A}$ & N/A & \\
\hline $\begin{array}{l}\text { Leigh syndrome, French- } \\
\text { Canadian type (LSFC) }\end{array}$ & 220111 & $1 / 40000$ & $1 / 2000$ & $1 / 23$ & LRPPRC & $>$ c.1061C>T (p.Ala354Val) & 0.99 & $510^{-5}$ & 1035 \\
\hline Tyrosinemia type I (TYRSN1) & 276700 & $1 / 120000$ & $1 / 1846$ & $1 / 20$ & $F A H$ & $\begin{aligned}- & \text { c.1062 5G>A } \\
& (\text { IVS12+5G+A) }\end{aligned}$ & 0.9 & $310^{-4}$ & 3839 \\
\hline \multirow[t]{3}{*}{ Cystic fibrosis (CF) } & \multirow[t]{3}{*}{219700} & \multirow[t]{3}{*}{$1 / 2000$} & \multirow[t]{3}{*}{$1 / 902$} & \multirow[t]{3}{*}{$1 / 15$} & \multirow[t]{3}{*}{ CFTR } & $\begin{array}{l}\text { c.1521-1523delCT } \\
\text { (p.Phe508del) }\end{array}$ & N/A & $710^{-3}$ & \multirow[t]{3}{*}{4951} \\
\hline & & & & & & $\begin{array}{r}c .489+1 \mathrm{G}>\mathrm{T} \\
(621+1 \mathrm{G}>\mathrm{T})\end{array}$ & $\mathrm{N} / \mathrm{A}$ & $610^{-5}$ & \\
\hline & & & & & & $\begin{aligned}- & c .1364 C>A \\
& \text { (p.Arg347Pro) }\end{aligned}$ & N/A & $210^{-5}$ & \\
\hline $\begin{array}{l}\text { Mucolipidosis } \\
\text { (I-cell disease) }\end{array}$ & 252500 & N/A & $1 / 6184$ & $1 / 39$ & GNPTAB & $\begin{array}{l}\text { c.3503_3504delTC } \\
\text { (p.Leu1168Glnfs) }\end{array}$ & $\mathrm{N} / \mathrm{A}$ & $410^{-4}$ & 464 \\
\hline \multirow{2}{*}{$\begin{array}{l}\text { Vitamin D-dependent rickets } \\
\text { type } 1 \text { (VDDR1) }\end{array}$} & \multirow[t]{2}{*}{264700} & \multirow[t]{2}{*}{ N/A } & \multirow[t]{2}{*}{$1 / 2916$} & \multirow[t]{2}{*}{$1 / 27$} & \multirow[t]{2}{*}{ CYP27B1 } & c.262delG (p.Val88Trpfs) & N/A & $310^{-5}$ & \multirow[t]{2}{*}{7677} \\
\hline & & & & & & $\begin{array}{l}\text { c.958delG (frameshift } \\
\text { after 87Tyr) }\end{array}$ & N/A & N/A & \\
\hline $\begin{array}{l}\text { Familial } \\
\text { dysbetalipoproteinemia (type } \\
\text { III hyperlipoproteinemia) }\end{array}$ & 617347 & $1 / 5000$ & $1 / 1000$ & $1 / 7$ & $A P O E$ & - Apo E2 allele & $\mathrm{N} / \mathrm{A}$ & $\mathrm{N} / \mathrm{A}$ & $81-84$ \\
\hline \multirow{3}{*}{$\begin{array}{l}\text { Lipoprotein lipase deficiency } \\
\text { (LPLD) }\end{array}$} & 238600 & & $1 / 5000$ & $1 / 40$ & $L P L$ & - c.644G >A (p.Gly215Glu) & N/A & $10^{-4}$ & 87160 \\
\hline & & $\begin{array}{l}1-21 \\
1000000\end{array}$ & & & & c.701C>T (p.Pro234Leu) & N/A & $410^{-5}$ & \\
\hline & & & & & & - c.829G >A (p.Asp277Asn) & N/A & $210^{-5}$ & \\
\hline Cystinosis & 219800 & $0.5-1.0 / 100000$ & $1 / 11939$ & $1 / 39$ & CTNS & - c. $414 \mathrm{G}>\mathrm{A}$ (p.Trp138X) & $\mathrm{N} / \mathrm{A}$ & $410^{-5}$ & 4 \\
\hline Zellweger syndrome (ZS) & 601539 & N/A & $1 / 12191$ & $1 / 55$ & PEX6 & $\begin{array}{l}\text { c.802_815del } \\
\text { (p.Asp268fs) }\end{array}$ & N/A & $10^{-5}$ & 611 \\
\hline Naxos disease (NXD) & 601214 & $\mathrm{~N} / \mathrm{A}$ & N/A & $\mathrm{N} / \mathrm{A}$ & JUP & - c.902A>G (p.Glu301Gly) & N/A & $10^{-5}$ & 147148 \\
\hline Autosomal dominant diseas & & & & & & & & & \\
\hline $\begin{array}{l}\text { Myotonic dystrophy type } \\
1 \text { (DM1) }\end{array}$ & 160900 & $2.1-14.3 / 100000$ & $158 / 100000$ & - & DMPK & - (CTG) repeat expansion & N/A & $N / A$ & 1298 \\
\hline Familial & 143890 & & & - & $L D L R$ & - prom_e1 deletion $>15 \mathrm{~kb}$ & N/A & N/A & 81107108113 \\
\hline hypercholesterolaemia (FH) & & $\begin{array}{l}\text { Heterozygous } \\
1 / 250\end{array}$ & $\begin{array}{l}\text { Heterozygous } \\
1 / 120\end{array}$ & & & - c.259T>G (p.Trp87Gly) & N/A & $210^{-5}$ & \\
\hline & & Homozygous & & & & - c.2000G >A (p.Cys667Tyr) & $N / A$ & $310^{-6}$ & \\
\hline & & $1 / 300000$ & & & & - c.1467C > G (p.Tyr489Ter) & N/A & $310^{-6}$ & \\
\hline Epidermolysis bullosa & 131760 & $6-30 / 100000$ & $\mathrm{~N} / \mathrm{A}$ & - & KRT5 & KRT5 : & & & 152153 \\
\hline simplex (EBS) & $\begin{array}{l}131900 \\
131800\end{array}$ & & & & KRT14 & $>\quad c .74 C>T$ (p.Pro25Leu) & N/A & $\mathrm{N} / \mathrm{A}$ & \\
\hline & & & & & & $>\quad c .449 \mathrm{C}>\mathrm{T}$ (p.Leu150Pro) & N/A & $\mathrm{N} / \mathrm{A}$ & \\
\hline & & & & & & KRT14: & & & \\
\hline & & & & & & - c.1130T>C (p.lleu377Thr) & N/A & N/A & \\
\hline
\end{tabular}

*https://gnomad.broadinstitute.org.

about 325 French-Canadian patients from 200 families originating from the Charlevoix and SLSJ regions ${ }^{19}$ where a higher incidence has been observed: the estimation of incidence and carrier frequency were 1/1932 live born infants and 1/22, respectively. ${ }^{19} 20$ ARSACS was for a long time recognised as a form of early-onset ataxia limited to Quebec, due to a founder effect. However, over time, several studies showed that ARSACS occurs elsewhere in the world, including in Europe and Asia, with significant clinical variability between patients. ${ }^{17}$ 21-24 Pathogenic variants in the gene Spastic Ataxia of Charlevoix-Saguenay (SACS) were first described in French-Canadian patients. ${ }^{25}$ The product of this gene is a very large cytoplasmic protein, sacsin, with a suggested potential chaperone activity. Over the years, the number of individuals with ARSACS harbouring pathogenic variants in the SACS gene has rapidly increased worldwide and close to
200 pathogenic variants have been reported. ${ }^{26} 27$ Two founder mutations in the SACS gene have been identified in FrenchCanadian patients, c.8844del (p.Ile2949fs) and c.7504C > T (p.Arg2502Cys). ${ }^{28} \mathrm{Up}$ to now, there is no effective treatment for ARSACS. Physiotherapy and exercises tailored to ataxia and medications such as baclofen to control spasticity in the early stage of the disease may joint contractures and prevent tendon shortening and, hence, may help postpone functional impairments. ${ }^{29}$ Urinary urgency and incontinence may be controlled with specific treatments. ${ }^{29}$ An Ataxia CharlevoixSaguenay Foundation was established in 1972 in Montreal in order to help the management and diagnosis of patients with ARSACS. In SLSJ, the Clinique des maladies neuromusculaires (CMNM) provides specialised adaptation and rehabilitation services to people with neuromuscular diseases 
such as ARSACS, and support to their families (https:// santesaglac.gouv.qc.ca/soins-et-services/deficience-physique/ clinique-des-maladies-neuromusculaires/).

\section{Agenesis of the corpus callosum and peripheral neuropathy (ACCPN,} MIM 218000)

Agenesis of the corpus callosum and peripheral neuropathy (Andermann syndrome) is an autosomal recessive motor and sensory neuropathy with agenesis of the corpus callosum. ACCPN manifests with progressive axonal degeneration and peripheral neuropathy leading to absence of deep tendon reflexes, atypical psychosis, mental retardation and growth delay. ${ }^{30}$ On cerebral imaging, around $67.2 \%$ of patients present partial or total corpus callosum agenesis. ${ }^{31}$ The mean age at death is 33 years. ${ }^{32}$ Children usually begin to walk at a mean age of 3.8 years and lose the ability to walk at a mean age of 13.8 years (Muscular Dystrophy Canada, 2013). The prevalence of this condition in the world is very low, as only a few cases have been reported outside Quebec. ${ }^{31}{ }^{33}$ In the population of SLSJ, the prevalence is $1 / 2117$ live births, and $1 / 23$ individuals is a carrier of the founder mutation. ${ }^{32}$ The causal gene is solute carrier family 12 member 6 (SLC12A6) located on chromosome band $15 \mathrm{q} 14$. It encodes the potassium-chloride cotransporter 3 (KCC3). Two pathogenic variants have been found in French-Canadians, c.2436delG (p.Thr813Profs) (161/162 alleles) and c.1584-1585delCTinsG (Phe529fsX531). ${ }^{30}$ No treatments are currently available. As the disease progresses, orthoses for upper and lower limbs and physiotherapy are beneficial to prevent contractures. Early developmental/educational intervention addresses cognitive delays. Neuroleptics may be used to treat psychiatric manifestations. ${ }^{30}$

\section{Leigh syndrome, French-Canadian type (LSFC, MIM 220111)}

Leigh syndrome, French-Canadian type or congenital lactic acidosis specific to SLSJ is an autosomal recessive form of cytochrome oxidase deficiency (COX, respiratory chain complex IV). This mitochondrial disease is diagnosed in children aged between 0 and 4 years and is characterised by developmental delay, hypotonia, elevated lactate levels in blood and cerebrospinal fluid, and high mortality in infancy. ${ }^{34}$ It affects $1 / 40000$ newborns worldwide. ${ }^{10}$ In SLSJ, this disorder affects $1 / 2000$ births, with a carrier rate of $1 / 23$ individuals. ${ }^{35} \mathrm{~A}$ genome-wide linkage-disequilibrium scan carried in 13 families from SLSJ localised the candidate region for the SLSJ cytochrome oxidase deficiency on chromosome $2 \mathrm{p} 16 .{ }^{10}$ Two years later, the responsible gene was identified as the leucine-rich pentatricopeptide repeat containing protein (LRPPRC) gene. It encodes for a mitochondrial and nuclear protein predicted to bind mRNA and thus regulates post-transcriptional mechanisms such as RNA stability, RNA modifications or RNA degradation. ${ }^{36} 37$ The majority of patients from SLSJ carry the homozygous founder mutation c.1061C $>\mathrm{T}$ (p.Ala354Val) in LRPPRC. ${ }^{35}$ To date, there is no treatment for this disease. Patients are encouraged to eat several small meals throughout the day in order to reduce the high-energy demands of digestion. During acute acidotic crises, management involves control of acidosis and provision of life-supporting care. ${ }^{35}$ In 1991, a patient and family association was established in SLSJ as well as an international multidisciplinary consortium in order to better understand the pathophysiology of this disease and advance the development of diagnosis and treatment.

\section{Tyrosinemia type I (TYRSN1, MIM 276700)}

Tyrosinemia type I (hepatorenal tyrosinemia) is an autosomal recessive metabolic disease. It manifests with renal tubulopathy, hypophosphatemic rickets and mild renal Fanconi syndrome, cirrhosis, hepatocellular carcinoma, and acute neurological crises and sometimes paralysis. ${ }^{8}$ The worldwide prevalence of hereditary tyrosinemia type $\mathrm{I}$ is $1 / 120000$ live births. ${ }^{38}$ However, the prevalence is much higher in SLSJ, where around 1/1846 newborns is affected and 1/20 individuals is a carrier. ${ }^{39}$ The responsible gene is fumarylacetoacetate hydrolase $(F A H)$, located on chromosome 15q23-25 and encoding fumaryl acetoacetate hydrolase (Fah). Pathogenic variants in this gene lead to a deficiency in Fah, involved in the catabolism of tyrosine. ${ }^{40}$ This deficiency causes an accumulation of metabolic products with high toxicity in the liver, kidneys and peripheral nerves. ${ }^{4142}$ The founder splice mutation c.1062 5G>A (IVS12+5G+A) is the main allele found in patients from the SLSJ region. ${ }^{43}$ Before 2005 and prior to the availability of nitisinone (a synthetic reversible inhibitor of 4-hydroxyphenylpyruvate dioxygenase), the only available curative therapy for tyrosinemia type I was liver transplantation. Since 2005 , the pharmacological medication nitisinone or NTBC (2-(2-nitro-4-trifluoromethylbenzoyl)-1,3-cyclohe xanedione) combined with a strict diet and close monitoring of disease progression is the standard management. ${ }^{42} 4445$ Liver transplantation is still offered to those with severe complications or if therapeutic response is not achieved. ${ }^{46}$ Recently, a CRISPR-Cas9-mediated correction of a FAH pathogenic variant in hepatocytes of a mouse model resulted in expression of the wild-type Fah protein in liver cells. ${ }^{47}$ This is promising for a future therapeutic avenue. Newborn screening for this condition is routinely offered in Quebec since 1970 as part of the provincial newborn screening programme. ${ }^{48}$

\section{Cystic fibrosis (CF, MIM 219700)}

Cystic fibrosis (CF) (mucoviscidosis) is an autosomal recessive disorder classically described as a triad of chronic obstructive pulmonary disease, exocrine pancreatic insufficiency and congenital bilateral agenesis of the vas deferens. ${ }^{8}$ In the world, CF incidence is approximately $1 / 2000$ and carrier rate about $1 / 22 .{ }^{49}$ In the population of European descent, CF has an incidence of $1 / 2500$ and a carrier rate of $1 / 25 .^{50}$ In Quebec, CF incidence is $1 / 2500$ and a carrier rate of $1 / 22$. In SLSJ, the incidence of cystic fibrosis reached 1/902 live births between 1975 and 1988. This corresponds to a carrier rate of $1 / 15 .^{51}$ $\mathrm{CF}$ is caused by pathogenic variants in the gene cystic fibrosis transmembrane conductance regulator (CFTR) on chromosome $7 \mathrm{q} 31.2 .^{52}$ Over 2000 disease-causing pathogenic variants have been reported in CFTR.$^{53}$ Three mutations are particularly frequent in the SLSJ population (c.1521-1523delCTT (p.Phe508del), c. $489+1 \mathrm{G}>\mathrm{T}(621+1 \mathrm{G}>\mathrm{T})$ and c.1364C $>\mathrm{A}$ (p.Arg347Pro)). As in most populations, p.Phe508del is the most frequent one. ${ }^{54}$ Three other pathogenic variants are present in at least three different families (c.579+1G $>\mathrm{T}$ $(711+1 \mathrm{G}>\mathrm{T})$, c.3067_3072del (p.Ile1023Val1024del) and c.3276C $>$ A (p.Tyr1092X)) in SLSJ. ${ }^{55} 56 \mathrm{CF}$ treatment is supportive, with pancreatic enzyme supplementation, antibioprophylaxis and respiratory therapy ${ }^{57}{ }^{58}$ Patients homozygous for the p.Phe $508 \mathrm{del}$ mutation, treated with a combination of a corrector and a potentiator of the mutated CFTR protein, showed some amelioration of respiratory function. ${ }^{59}{ }^{60}$ Since 2017, screening for CF is available for all Quebec newborns, allowing for early diagnosis and management of children with 
CF. Cystic Fibrosis Canada, a national charitable not-for-profit corporation, was created in 1960 in order to help patient management and treatment development for CF. In SLSJ, a CF clinic was also established and offers diagnosis and treatment for children and adults with CF.

\section{Mucolipidosis (MLII, MIM 252500)}

Mucolipidosis (MLII) (I-cell disease) is a rare autosomal recessive form of lysosomal storage disorder. This disease is fatal in childhood and causes developmental delay, coarse facial features with hyperplastic gums, dislocation of the hips, short stature, thickened skin and generalised hypotonia. ${ }^{6162}$ MLII prevalence at birth in SLSJ was reported to be $1 / 6184$, with a carrier rate of $1 / 39$ which is the highest frequency documented worldwide. ${ }^{4}$ MLII is caused by a deficiency of the lysosomal enzyme $\mathrm{N}$-acetylglucosamine-1-phosphotransferase (GNPTAB), an enzyme required for the mannose 6-phosphate tagging of newly synthesised lysosomal enzymes. ${ }^{63}$ A single founder mutation c.3503 3504delTC (p.Leu1168Glnfs) was present in 100\% of MLII obligatory carriers of SLSJ origin and is responsible for MLII in this population. ${ }^{64}$ Although this mutation has been observed elsewhere, it reaches the highest reported frequency in SLSJ. ${ }^{6566}$ No cures or specific therapies for MLII currently exist. Management of symptoms and supportive care are the only treatments available. For example, interactive programmes to stimulate cognitive development, physical and/or speech therapy may be beneficial for patients (https://www.orpha.net). For those with severe mouth pain and infections, gingivectomy may be considered. ${ }^{6768}$ Respiratory support and assisted ventilation may be required for some patients. ${ }^{69}$

\section{Vitamin D-dependent rickets type 1 (VDDR1, MIM 264700)}

Vitamin D plays an essential role in ensuring bone growth, mineral metabolism and cellular differentiation. ${ }^{70}$ Vitamin D dependency type I (VDDR1), also referred to as pseudo-vitamin $\mathrm{D}$-deficiency rickets (PDDR), is an autosomal recessive disease due to renal 25(OH)-vitamin D 1a-hydroxylase deficiency, the key enzyme in vitamin D metabolism. This results in impaired synthesis of 1,25-dihydroxyvitamin $\mathrm{D}$, the active form of vitamin D. ${ }^{71-73}$ VDDR1 is characterised by early onset of rickets, hypocalcemia, hypophosphatemia and secondary hyperparathyroidism that appeared in the first or second year of life. ${ }^{74}$ This disorder is rarely described in the world but was reported to be particularly common in the French-Canadian population. In SLSJ, it was recognised for the first time in $1970^{75}$ and its prevalence was estimated to be $1 / 2916$ live births giving a carrier frequency of $1 / 27$ inhabitants. ${ }^{4}$

VDDR1 is caused by pathogenic variants in the 25-hydroxyvitamin D 1-alpha-hydroxylase gene (CYP27B1) that was mapped to chromosome $12 \mathrm{q} 14$ by genotyping FrenchCanadian families. ${ }^{72}$ Two founder mutations were identified in French-Canadian patients, the c.262delG (p.Val88Trpfs) mutation was found in three patients at the homozygous state ${ }^{76}$ and c.958delG (frameshift after 87Tyr) mutation was described on $11 / 12$ alleles. ${ }^{77}$ This suggests the existence of more than one founder effect of this disease in that population. The clinical phenotype of this disorder is completely corrected by daily administration of physiological doses of hormonally active, synthetic, vitamin D analogue (calcitriol). ${ }^{78}$

\section{Autosomal recessive lipid disorders}

The molecular genetic basis is well established for 25 monogenic dyslipidemias affecting blood levels of low-density lipoprotein cholesterol (LDL-C), triglycerides, high-density lipoprotein cholesterol (HDL-C), other lipids or fat metabolism. ${ }^{79}$ Although the majority of known monogenic dyslipidemias are encountered among French Canadians, familial dysbetalipoproteinemia and lipoprotein lipase deficiency (LPLD) are two autosomal recessive disorders having a significantly higher-than-expected prevalence in the Charlevoix-SLSJ population. Familial dysbetalipoproteinemia (MIM 617347), formerly known as type III hyperlipidemia, is a treatable hypertriglyceridemic phenotype most often associated with lipoprotein remnants accumulation, apolipoprotein E2 (APOE2) homozygosity, palmar xanthomas, and increased risk of coronary and peripheral artery disease. ${ }^{80}$ Its estimated worldwide prevalence is $1 / 5000$ but it is fivefold more frequent in the SLSJ due to a higher prevalence of APOE2, as estimated from the regional sample of the Quebec Heart Health Survey in $1991^{81}$ and other sources. ${ }^{82-84}$ LPLD (MIM 238600) is the main cause of the familial chylomicronemia syndrome (FCS) which is due to the presence of null variants in the LPL gene or in genes directly affecting LPL bioavailability, such as APOC2, GPIHPB1, APOA5 or MLF1. ${ }^{85}$ LPLD is characterised by chylomicronemia (very severe hypertriglyceridemia), lipemia retinalis, eruptive xanthomas, and increased risk of recurrent acute pancreatitis and other morbidities. The prevalence of FCS is estimated at 1-2 cases per million worldwide, but it is 200 -fold more frequent in the SLSJ-Charlevoix population. ${ }^{81} 86$ The higher prevalence of LPLD in the SLSJ is due to the high frequency of the c.701C $>$ T (p.Pro234Leu) variant ${ }^{8788}$ and, to a lesser extent, the c.644G $>$ A (p.Gly215Glu) variant in $L P L$ gene, ${ }^{88}$ although other loss-offunction pathogenic variants, in both $L P L$ and $L P L$-related genes, also contribute to the FCS phenotype in this region. The treatment of LPLD is a very strict low-fat diet. Effective therapies are in advanced clinical development for LPLD, including apoC-III antisense oligonucleotides (ASO) or small interfering RNA. ${ }^{89-91}$ LPL gene replacement therapy has been used and a next generation is in development. ${ }^{92} 93$ ANGPTL3 inhibitors (monoclonal antibodies, ASO or siRNA) are also in clinical development for severe hypertriglyceridemia and chylomicronemia. ${ }^{94}$ Oligogenic and polygenic causes of chylomicronemia also exist and are 50to 100 -fold more common than monogenic, autosomal recessive, causes. ${ }^{95}$

\section{Rare autosomal dominant diseases with higher prevalence in Saguenay-Lac-Saint-Jean population} Myotonic dystrophy type 1 (DM1, MIM 160900)

Myotonic dystrophy type 1 (DM1), also known as dystrophia myotonica or Steinert disease, affects the muscular system and also the central nervous, ocular, respiratory, cardiovascular, digestive, endocrine and reproductive systems. ${ }^{9697}$ Its prevalence ranges between 2.1 and 14.3/100 000 worldwide. ${ }^{98}$ In SLSJ, the prevalence was estimated in 2010 to be $158 / 100000$, which is the highest reported prevalence in the world. ${ }^{12}$ In 1985, 406 patients with DM1 were known in SLSJ. From 1985 to 2010, 352 new patients with DM1 were identified and 321 patients died. ${ }^{12}$ The local founder effect of this disease in SLSJ was confirmed by haplotype analysis. ${ }^{99}$ The genetics of this condition is characterised by anticipation due to a highly instable trinucleotide (CTG) repeat expansion within the $3^{\prime}$ untranslated region of the dystrophia myotonica protein kinase gene (DMPK) at chromosome $19 \mathrm{q} 13.3 .{ }^{100}$ Treatment is palliative and can include the use of ankle-foot orthoses, wheelchairs, or other assistive tools, special education programmes for children with DM1, and when appropriate, treatment of hypothyroidism, management of pain, consultation with a cardiologist for symptoms 
or electrocardiogram evidence of arrhythmia, and removal of cataracts if present. ${ }^{101} 102$ In SLSJ, patients can benefit from services offered by the Clinique des maladies neuromusculaires (CMNM). Roussel et al showed that strength/endurance training programmes in patients with DM1 leads to skeletal muscle adaptations linked to muscle growth. ${ }^{103}$

\section{Familial hypercholesterolaemia (FH, MIM 143890)}

Familial hypercholesterolaemia (FH) is an autosomal codominant disorder of cholesterol metabolism. The world prevalence is estimated at 1/250 for heterozygous FH and 1/300 000 for homozygous FH. ${ }^{104-106}$ The overall prevalence of FH is known to be higher in several founder clusters, including French Canadians. Although the FH prevalence varies from one Quebec region to another, ${ }^{107}$ it was estimated at $1 / 80$ in the SLSJ region in the early 1990 s. ${ }^{108} \mathrm{FH}$ is most often caused by loss-of-function pathogenic variants in the low-density lipoprotein (LDL)-receptor $(L D L R)$ gene, although variants in APOB, PCSK9 and LDLRAP1 genes are also FH causing. The most frequent mutation in SLSJ is the non-null c.259T $>\mathrm{G}$ (p. Trp87Gly) in $L D L R$ gene. ${ }^{109}$ For a long time, a large $(>15 \mathrm{~kb})$ deletion was considered as the most frequent mutation in Quebec, but this was due to the severity of the FH phenotype associated with this null deletion. Despite the clinical utility of molecular testing, the diagnosis of $\mathrm{FH}$ is primarily clinical. ${ }^{110-112}$ On top of life habits, statin therapy, with or without ezetimibe, is the standard of care for $\mathrm{HeFH}$ and can be started during childhood. ${ }^{113-115}$ Monoclonal antibodies or siRNA agents inhibiting proprotein convertase subtilisin/kexin type 9 (PCSK9), a serine protease that binds and promotes the lysosomal degradation of the LDLR, and incrementally decrease LDL-C in $\mathrm{HeFH}$ by more than $50 \%$ are now available in affected adults ${ }^{116-119}$ and are currently under advanced clinical investigation in the severe paediatric $\mathrm{HeFH}$ population. ${ }^{120-122}$ PCSK9 inhibitors, however, require some residual LDL receptor bioavailability and are therefore less effective or non-effective in homozygous $\mathrm{FH}(\mathrm{HoFH})$ patients. For HoFH and refractory FH, LDL receptor-independent agents have been developed, including lomitapide, a microsomal triglyceride transfer protein (MTTP) inhibitor, ${ }^{123-125}$ and evinacumab, an Angiopoietin-like 3 (ANGPTL-3) inhibitor. ${ }^{126-128}$ Given the prevalence of FH in SLSJ, the use of expensive therapies such as PCSK9 inhibitors, lomitapide or evinacumab might constitute an important socioeconomic hurdle. ${ }^{124}$

\section{Other rare Mendelian diseases in Saguenay-Lac-Saint-Jean population}

As discussed previously, on top of recessive or dominant disorders being more prevalent in SLSJ, several other genetic disorders are regularly diagnosed in this region and are the object of clinical intervention or clinical research. These include well-documented lipid disorders such as elevated lipoprotein (a) (Lp(a)), abetalipoproteinemia, ATP-binding cassette A1 (ABCA1) deficiency, lecithin-cholesterol acyltransferase (LCAT) deficiency, chylomicron retention disease, lipid storage diseases and rare causes of non-alcoholic steatohepatitis (NASH) to name a few, as well as the diseases described later.

\section{Cystinosis (MIM 219800)}

Cystinosis (MIM 219800) is a lysosomal storage disease with autosomal recessive transmission. It is characterised by high accumulation of the amino acid cystine inside the lysosomes of cells due to a defect in cystine transport. ${ }^{129} 130$ This cystine deposits begins during fetal life and affects various tissues leading to failure to thrive, disturbance of renal function, ocular impairment and hypothyroidism. ${ }^{131132}$ The worldwide incidence of this metabolic disorder is estimated to $0.5-1.0 / 100000$ live births. ${ }^{133}$ In SLSJ, between 1971 and 1990, eight cases were identified and thus the incidence was calculated to be 1/11 939 births and carrier rate to $1 / 39 .{ }^{4}$ High incidence rate was also observed in the founder population in the province of Brittany, France (1/26 000 live births). ${ }^{134}$

In 1998, Town et al mapped the gene cystinosin, lysosomal cystine transporter (CTNS) on chromosome $17 \mathrm{p} 13$ and confirmed its responsibility of cystinosis. This gene is encoding for the lysosomal membrane protein cystinosin, transporting cystine out of the lysosomal compartment. ${ }^{135}$ More than 100 pathogenic variants have been further reported within this gene in the literature. ${ }^{133}$ Mutational analysis of 20 cystinosis FrenchCanadian families identified five pathogenic variants, from which two are novel. One mutation, c. 414G>A (p.Trp138X), previously found in the Irish population (but not French), accounted for 40\%-50\% of cystinosis alleles in Quebec suggesting a probable Irish origin of this mutation in French-Canadian patients. ${ }^{131}$

For over 20 years, cysteamine is used for the treatment of cystinosis. This agent decreases intracellular cystine resulting in slows organ deterioration and delaying the onset of endstage renal disease. ${ }^{136} 137$ Although this cystine-depleting agent does not treat the disease, it highly improves the overall prognosis. ${ }^{132138}$ The side effects of cysteamine include stomach problems, unusual breath, sweat odour and allergic reactions. ${ }^{139} \mathrm{~A}$ novel aminoglycoside (ELX-02) is now under investigation as a novel read-through therapy without cytoxicity. ${ }^{140}$

\section{Zellweger syndrome (ZS, MIM 601539)}

Zellweger syndrome (ZS) is an autosomal recessive condition due to a peroxisome biogenesis dysfunction. This leads to developmental defects and progressive neurological involvement and often results in death in the first year of life. ${ }^{141}$ The world incidence of ZS is $1 / 50000-100000$ live births. ${ }^{142}$ For some years, increased incidence of ZS has been suspected in French Canadians in SLSJ $^{6}$ and was calculated to be $1 / 12191$ live births, with a carrier rate of $1 / 55 .{ }^{11} \mathrm{ZS}$ is genetically heterogeneous and can be caused by pathogenic variants in any of 13 peroxisomal biogenesis factor (PEX) genes. ${ }^{143}$ PEX1 and PEX6 pathogenic variants account for $70 \%$ and $10 \%-16 \%$ of all cases, respectively. ${ }^{143} 144$ The homozygous pathogenic variant c. $802 \_815 \mathrm{del}$ (p.Asp268fs) in PEX6 was identified in five SLSJ patients. ${ }^{-11}$ This pathogenic variant was observed only one time in the literature, in a US patient with unknown ethnicity. ${ }^{145}$ No close relationship between the five patients with ZS from SLSJ was identified which provides strong evidence that the c. 802815 del variation in PEX6 is a founder mutation in SLSJ and suggests that this could be a relevant target for carrier screening in this population. If we consider an a priori estimated carrier frequency of $1 / 55$, about 3000 individuals would have to be screened to find one carrier couple at $25 \%$ risk of having an affected child. ${ }^{11}$ There is currently no cure or effective treatment for ZS. Management is supportive and based on the signs and symptoms. For example, infants with feeding issues may require placement of a feeding tube to ensure proper intake of calories. Symptomatic therapy may also include hearing aids, cataract removal in infancy, corrective lenses, vitamin supplementation, primary bile acid therapy, adrenal replacement, antiepileptic drugs, and possibly monitoring for hyperoxaluria. ${ }^{141}$ 
Naxos disease (NXD, MIM 601214)

Naxos disease (NXD) is an autosomal recessive disorder that combines palmoplantar keratoderma, peculiar woolly hair and arrhythmogenic right ventricular cardiomyopathy. It was first described in the island of Naxos, Greece. ${ }^{146}$ Since then, other cases were reported in Turkey, other Aegean Islands, Italy, Israel, Saudi Arabia, India, Argentina and Ecuador. ${ }^{147}$ In 2017, seven unrelated patients of French-Canadian descent were diagnosed with this disease. Five of these patients came from the SLSJ or Charlevoix regions. All the cases shared the same novel homozygous pathogenic variant in exon 5 of the plakoglobin (JUP) gene on chromosome 17q21: c.902A>G (p.Glu301Gly). ${ }^{148}$ Authors suggest that could be a founder mutation. Further studies are needed to confirm the pathogenicity of this variation and to confirm its founder origin. Management of NXD includes implantation of an automatic cardioverter defibrillator to prevent sudden cardiac arrest, antiarrhythmic drugs to prevent recurrences of episodes of sustained ventricular tachycardia and classical pharmacological treatment for congestive heart failure, while heart transplantation is used for patients with late-stage heart failure. ${ }^{149}$

\section{Epidermolysis bullosa simplex (EBS-loc, MIM 131800; EBS-gen} intermed, MIM 131900; EBS-gen sev, MIM 131760)

Epidermolysis bullosa simplex (EBS) is a clinically and genetically heterogeneous skin disorder characterised by blistering of the skin following minor trauma as a result of cytolysis within the basal layer of the epidermis. Most subtypes are autosomal dominant inherited. The localised form is characterised by blistering primarily on the hands and feet. The other two main types of EBS include the milder generalised intermediate type and the generalised severe types. ${ }^{150}$ All three forms are caused by pathogenic variants in the keratin 5 (KRT5) or keratin 14 (KRT14) genes. ${ }^{151}$ EBS worldwide prevalence is estimated to be approximately 6-30/1 000000 live births. ${ }^{152}$ There are 230 known causative pathogenic variants for EBS in KRT5 and KRT14 including 123 in KRT5 and 107 in KRT14 (http://www.interfil.org/). From 2007 to 2019, ten EBS French-Canadian patients were described in Quebec, including four from SLSJ. Two SLSJ patients carried pathogenic variants in KRT5 (c.74C $>\mathrm{T}$ (p.Pro25Leu), c.449C $>\mathrm{T}$ (p.Leu150Pro)) and the two others share the same pathogenic variant in KRT14 gene (c.1130T >C (p.Ileu377Thr)) with no known familial relationship. ${ }^{153}$ There is no treatment for EBS and the clinical management is primarily palliative, focusing on supportive care to protect the skin from blistering, and the use of dressings that will not further damage the skin and will promote healing. Blister formation can be limited by applying aluminium chloride to palms and soles. Hyperkeratosis of the palms and soles can be prevented by using keratolytics and softening agents. Treatment with topical and/or systemic antibiotics or silver-impregnated dressings or gels can be used for limiting secondary infections. Avoiding higher weather temperature and activities that damage the skin is typically recommended..$^{150}$ Several potential attempts of protein therapy and gene therapy to cure EBS were initiated and are under development. ${ }^{154}$

\section{Organisation of resources and services for patients and families}

In 1980, a not-for-profit organisation (La Corporation de recherche et d'action sur les maladies héréditaires; CORAMH) (www.coramh.org) was founded by Gérard Bouchard and colleagues. ${ }^{155}$ Its mission is educating the SLSJ population and providing information about severe hereditary diseases known to have a higher frequency in the region (table 1). CORAMH was of great help to raise awareness about the medical implications for individuals in SLSJ, including modes of transmission, clinical features and reproductive options. Moreover, CORAMH contributes at the community level to the offer of support to individuals affected by genetic diseases and their families, and also contributes to promote scientific research on various issues linked to these diseases and to the needs of affected individuals. Throughout the years, this expertise has facilitated the implementation and the development of specialised services in the region, including the Clinique des maladies neuromusculaires (1982) which currently provides services to over 1000 individuals with neuromuscular diseases and the regional chapters of Muscular Dystrophy Canada (1983). Moreover, CORAMH participated to the creation of the tyrosinemia association (1984) (Groupe d'Aide aux Enfants Tyrosinémiques du Québec, https:// gaetq.org), as well as the creation of the lactic acidosis association (1990) (Association de l'acidose lactique du Saguenay-LacSaint-Jean, www.aal.qc.ca). CORAMH has always supported and has promoted research activities. It has participated in several committees and task forces with government organisations, including the implementation of a reliable screening test to identify carriers of tyrosinemia in SLSJ in 1995 in collaboration with the Applied Genetic Medicine Network. CORAMH was one of the most important partners of the first international community genetics meeting, which has been held in June 2000 under the sponsorship of the World Health Organization (WHO) and Health Canada. ${ }^{155-157}$ The CORAMH experience has also been presented in Geneva at the WHO consensus meeting on FH (Gaudet and Hegele, as coauthors of the WHO FH experts consensus (World Health Organization 1998)) and has participated in a consultative committee for the Quebec government about orientations in human genetics in the last years (figure 2). Patient associations, local healthcare professionals and specialised clinics have joined CORAMH to get involved in their education and research programme (figure 3 ).

In 2000, CORAMH joined and received support from the Canadian Institute for Health research (CIHR) Community Alliance on Health Research (CAHR) in community genetics (CIHR grant \#CAR43283) and from the Canada research Chair in community genetics. ${ }^{15} 156$ At the end of the CIHR/CAHR programme in 2005, CORAMH, the SLSJ health authorities and the Institut national de santé publique du Québec (INSPQ) joined the 5-year CIHR Interdisciplinary Health Research Team (IHRT) in community genetics (ECOGENE-21). Both the CAHR and IHRT (CIHR grant \#CTP-82941) programmes provided support to the conception and development of the community carrier screening programme. During this period, CORAMH pursued the development of mobilisation and knowledge transfer tools and participated in the activities of a multidisciplinary working group whose mandate was to document the situation of genetic, orphan diseases in the SLSJ region. This committee submitted a brief to the provincial government that recommended the implementation of a pilot project on carrier testing for four autosomal recessive disorders. In 2010, the CIHR decided to not renew the IHRT programme and ECOGENE-21 became a not-for-profit organisation dedicated to access to health innovations for unmet medical needs. After almost 10 years of studies and planning, the Quebec Ministry of Health and Social Services (MSSS) launched a pilot population-based carrier-screening programme in SLSJ to offer carrier screening for a selected set of autosomal recessive diseases: spastic ataxia of Charlevoix-Saguenay (ARSACS), the agenesis of the corpus callosum with/without peripheral neuropathy (ACCPN), the Leigh syndrome, French-Canadian 


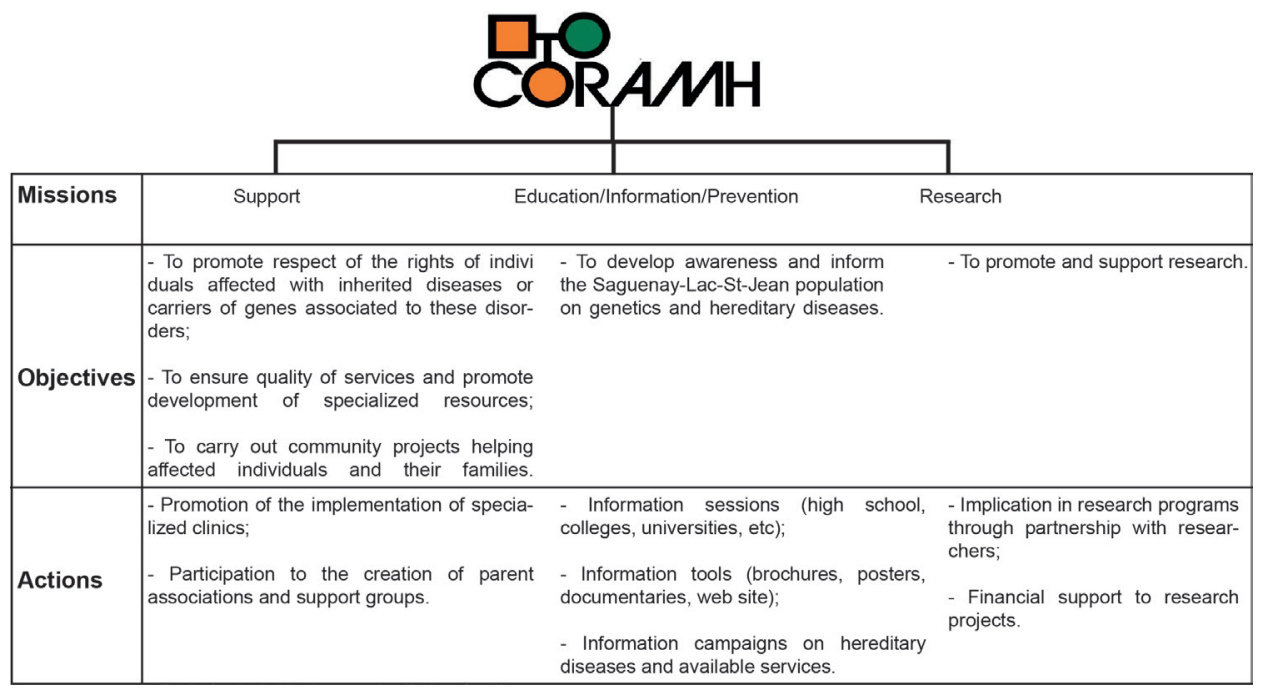

Figure 2 CORAMH in the Saguenay-Lac-Saint-Jean (SLSJ) region. The Corporation de recherche et d'action sur les maladies héréditaires (CORAMH) activities combine education programmes, support to affected individuals and their families, research promotion and community involvement. The main goal of CORAMH is to provide information on the basics of genetics and heredity and on the most frequent hereditary diseases in SLSJ and to describe the available services (eg, specialised clinics, genetic counselling, Regroupement québécois des maladies orphelines (RQMO) and support groups) through presentations in high schools, vocational schools, colleges and university health programmes. The CORAMH programmes also target workers in their workplaces as well as members of various social clubs and lay organisations. CORAMH has also developed a plethora of information and prevention tools that present the problematic hereditary diseases in the region and its consequences on affected individuals and their families. These tools include brochures, posters and documentaries, as well as a website (www.coramh.org). CORAMH also supports and has promoted research about genetic diseases at the national and international level.

type (LSFC) and the hereditary tyrosinemia type 1 (TYRSN1) (https://www.sante.gouv.qc.ca/tests4maladies). The carrier screening testing for the four mentioned disorders includes all five frequent mutations reported in the region. This allows a carrier detection rate in this population between $97 \%$ and $100 \%$ depending on the disease tested which is relatively high considering only five mutations were tested (this is an advantage of the founder effect).

The test is free and offered to couples planning a pregnancy (preconception) and couples with an ongoing pregnancy (prenatal). To be eligible for this test, individuals needed to be over 18 years of age and either are planning to have children or have an ongoing pregnancy under 16 weeks of pregnancy (later during pregnancy, they are seen in a prenatal clinic). For this pilot programme, they also had to live in SLSJ and have at least one grandparent born in SLSJ (https://www.inesss.qc.ca). Before doing the carrier screening test, all individuals had a face-toface $45 \mathrm{~min}$ information session given by a well-trained nurse about the target diseases, the risks and benefits of the test, and its possible results. Information about all reproductive options available to carrier couples was also presented. All individuals needed to sign a consent form before doing the screening test and were advised they can withdraw from the test at any time after blood collection. ${ }^{16}$ After the samples were analysed, all received a letter reporting their results: carriers were informed about their status by phone call with the nurse who collected the samples and carrier couples were in addition offered genetic counselling sessions. In 2012, the INSPQ, with the support of the CIHR/IHRT (CIHR grant \#82941), completed the evaluation of the pilot programme. At that time, a total of 3915 individuals were already screened and 846 carriers identified. ${ }^{158} 159$ The report acknowledged the pilot project was a success and recommended the carrier screening tests should be offered on a continuous basis.
In 2018, the MSSS announced the deployment of the screening tests offer in the Province of Quebec for all potential carriers of at least one of the four diseases with increased incidence in SLSJ. As the same diseases affected Charlevoix and Haute-CôteNord (on the north of SLSJ) regions, these populations were also prioritised for the screening test. Admissible individuals need to (1) be over 18 years; (2) have at least one of their four biological grandparents born in SLSJ, Charlevoix or Haute-CôteNord regions; and (3) plan to have children (preconception or within 16 weeks of pregnancy) (https://www.sante.gouv.qc.ca/ tests 4 maladies). The test remains free but is now made at home on self-sampled buccal cells. After an online registration, which includes an information session about the test, the four genetic diseases and the possible results, the collection kit (two buccal swabs, instructions and consent form) is sent and returned by mail. Results are shared following the same procedures as in the pilot project.

\section{CONCLUSION}

The initial founder effect and subsequent population movements on the Quebec territory have strongly impacted the genetic load of the current population of French-Canadian descent. These migrations have resulted in a series of regional and local founder effects leading to an increased frequency of specific deleterious mutations and shaping their geographical distribution. In the SLSJ region, numerous research projects have been conducted over the past 40 years on the clinical, epidemiological and demogenetic aspects of some of these mutations and the associated genetic conditions. This work has confirmed that the elevated frequency of these disorders is the consequence of subsequent founder effects and cannot be explained by consanguineous marriages. ${ }^{14} 15$

These studies have also led to the creation in 1980 of a community association (CORAMH) aiming at developing public 


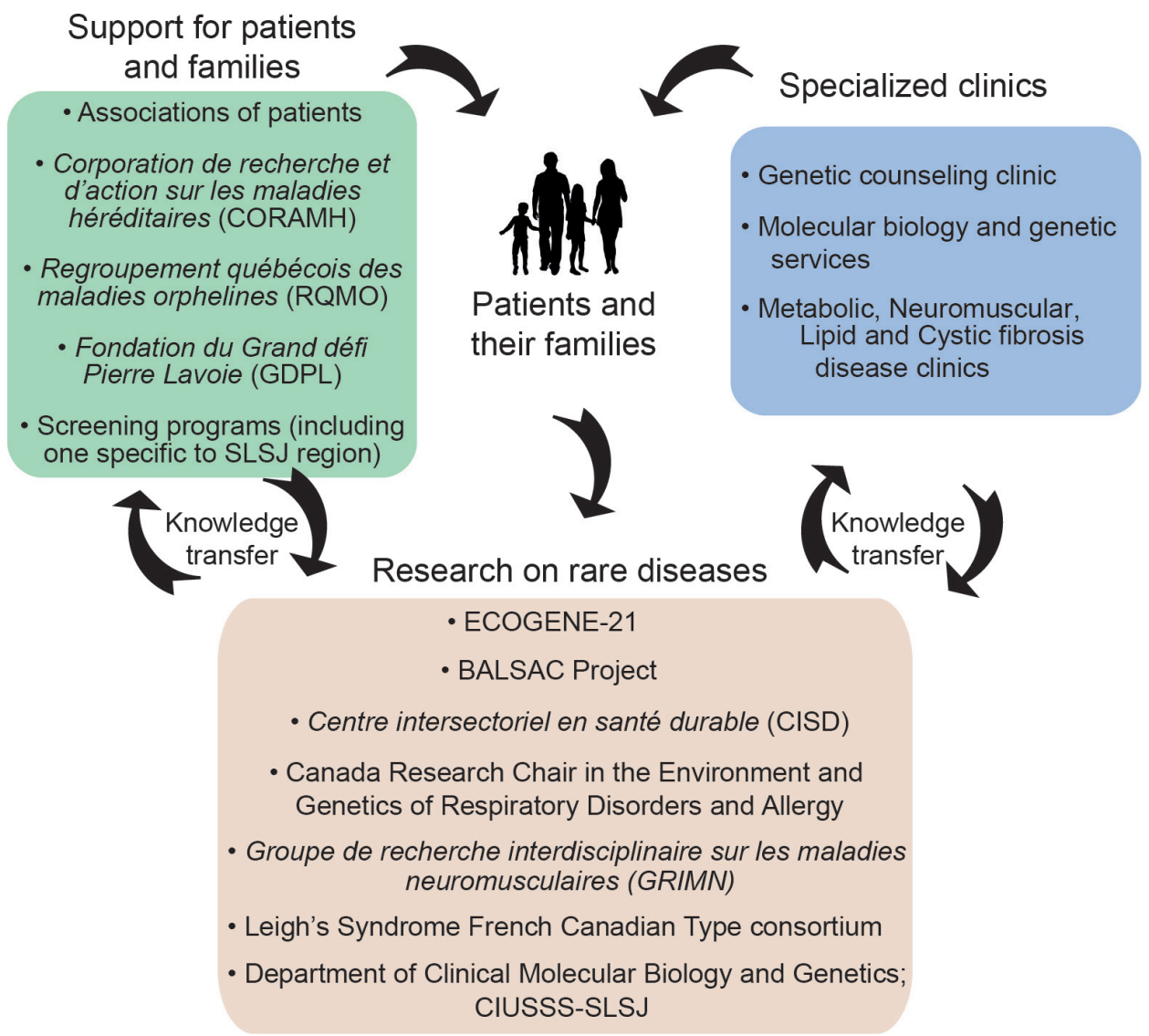

Figure 3 The network of organisations specialising in genetic diseases in Saguenay-Lac-Saint-Jean (SLSJ) region. Many resources of information on diseases exist in SLSJ region (patients associations, the Corporation de recherche et d'action sur les maladies héréditaires (CORAMH), the Réseau Québécois sur les maladies orphelines (RQMO), the Grand défi Pierre Lavoie (GDPL) and specialised clinics). These organisations support patients and their families by different means and services. ECOGENE-21 is devoted to access to innovation for unmet medical needs, helps to identify new biological pathways and disease markers, and develops diagnostic and screening tools, innovative treatments and new knowledge and technologies, through genetic research and its application to clinical practice and disease prevention. Canada Research Chair in the Environment and genetics of respiratory disorders and allergy, the Centre intersectoriel en santé durable (CISD) and Leigh's syndrome French-Canadian consortium are working on promoting scientific research on these disorders in order to improve treatment and alleviate their burden on the SLSJ population.

awareness on the various issues linked to the genetic disorders found in the region, promoting research and offering support to affected individuals and their families. CORAMH and partners have supported the implementation in 2010 of a pilot project aimed at offering screening tests on a voluntary basis for four genetic disorders with a higher prevalence in the region. These diseases are rare in the world and usually have no treatment, which increases the challenges for patients who are affected, clinicians, researchers and the SLSJ population as a whole. Since 2018, the programme is offered in the entire Province of Quebec.

Finally, there is a need to pursue the study of the current genetic make-up of the SLSJ population and take into account the evolution of the population including ageing and the decrease of the population size, outmigration of individuals with SLSJ ancestry and the arrival of newcomers from other regions of Quebec or with other ethnocultural backgrounds. This is essential to better understand the prevalence and distribution of genetic diseases in the population and organise genetic screening and testing services accordingly.

Our paper summarises key elements of the recent literature about genetic disorders in SLSJ and offer a portrait for geneticists, clinicians, health professionals and scientists of the current situation in SLSJ. In doing so, we hope to contribute to the sound management of genetic diseases and to the development of intervention strategies that meet the needs of the SLSJ population and abroad.

\section{Author affiliations}

'Département des sciences fondamentales, Université du Québec à Chicoutimi, Chicoutimi, Québec, Canada

${ }^{2}$ Centre intersectoriel en santé durable (CISD), Université du Québec à Chicoutimi, Chicoutimi, Québec, Canada

${ }^{3}$ Département de biochimie et de génomique fonctionnelle, Université de Sherbrooke, Sherbrooke, Québec, Canada

${ }^{4}$ Centre intégré universitaire de santé et de services sociaux du Saguenay-Lac-SaintJean, Hôpital de Chicoutimi, Chicoutimi, Québec, Canada

${ }^{5}$ Centre intégré universitaire de santé et de services sociaux du Saguenay-Lac-SaintJean, Clinique de maladies neuromusculaires, Jonquière, Québec, Canada

${ }^{6}$ Centre Hospitalier universitaire Sainte-Justine, Université de Montréal, Montreal, Québec, Canada

${ }^{7}$ ECOGENE-21 et le département de médecine, Université de Montréal, Montreal, Québec, Canada

${ }^{8}$ Département des sciences humaines et sociales, Université du Québec à Chicoutimi, Chicoutimi, Québec, Canada

Correction notice This article has been corrected since it was published Online First. The name of Dr Philippe M Campeau, and references 81, 116 and 126 have been corrected.

Acknowledgements $\mathrm{CL}$ is the director of the Centre intersectoriel en santé durable de I'UQAC and the chair holder of the Canada Research Chair tier one in the Environment and Genetics of Respiratory Disorders and Allergies (www.chairs.gc. 
ca). CL, PC and MB are scientific members of the CERMO-FC (www.cermofc.uqam. $\mathrm{ca} /)$. LB is a senior research scholar from the Fond de la recherche du Québec - santé (FRQS) and a member of the FRQS-funded Centre de recherche du CHUS (affiliated to the Centre hospitalier universitaire de Sherbrooke). DG is the scientific director of ECOGENE-21 and the Université de Montréal Community Genomic Medicine Centre (CMGC). We thank Anne-Marie Boucher-Lafleur for her help in producing the figures.

Contributors MB performed the research and wrote the first version. $\mathrm{CL}$ designed, supervised and contributed to the manuscript, as well as revised and approved the version for publication. $\mathrm{LB}, \mathrm{DB}, \mathrm{PC}, \mathrm{DG}, \mathrm{A}-\mathrm{ML}, \mathrm{JM}, \mathrm{CL}, \mathrm{CM}$ and $\mathrm{HV}$ are involved in rare diseases research projects. $\mathrm{LB}, \mathrm{DB}, \mathrm{PC}, \mathrm{DG}, \mathrm{A}-\mathrm{ML}, \mathrm{JM}, \mathrm{CM}$ and $\mathrm{HV}$ contributed to the writing and editing of specific sections. All the listed authors have reviewed the manuscript and have approved its final version for publication.

Funding Soft funds from the Canada Research Chair in the Environment and genetics of respiratory diseases and allergy.

Map disclaimer The depiction of boundaries on the map(s) in this article does not imply the expression of any opinion whatsoever on the part of BMJ (or any member of its group) concerning the legal status of any country, territory, jurisdiction or area or of its authorities. The map(s) are provided without any warranty of any kind, either express or implied.

\section{Competing interests None declared.}

Patient consent for publication Not required.

Provenance and peer review Not commissioned; externally peer reviewed.

Open access This is an open access article distributed in accordance with the Creative Commons Attribution Non Commercial (CC BY-NC 4.0) license, which permits others to distribute, remix, adapt, build upon this work non-commercially, and license their derivative works on different terms, provided the original work is properly cited, appropriate credit is given, any changes made indicated, and the use is non-commercial. See: http://creativecommons.org/licenses/by-nc/4.0/.

\section{ORCID iDs}

Philippe M Campeau http://orcid.org/0000-0001-9713-7107

Catherine Laprise http://orcid.org/0000-0001-5526-9945

\section{REFERENCES}

1 Charbonneau H, Desjardins B, Légaré J, Denis H. The population of the St-Lawrence Valley, 1608-1760. In: Haines MR, Steckel RH, eds. A population history of North America. Cambridge: Cambridge University Press, 2000: 99-142.

2 Bouchard G, De Braekeleer M. Histoire d'un génome. In: Population et génétique dans l'est du Québec. Presses de l'Université du Québec, 1991.

3 Pouyez C, Lavoie Y, Bouchard G, Roy R. Les Saguenayens. Introduction à I'histoire des populations du Saguenay, XVle-XXe siècles. Presses de I'Université du Québec, 1983.

4 De Braekeleer M. Hereditary disorders in Saguenay-Lac-St-Jean (Quebec, Canada). Hum Hered 1991:41:141-6.

5 Gauvreau D, Bourque M. Mouvements migratoires et familles : le peuplement du Saquenay avant 1911. Revue d'histoire de l'Amérique française 1988;42:167-92.

6 Scriver CR. Human genetics: lessons from Quebec populations. Annu Rev Genomics Hum Genet 2001;2:69-101.

7 Lavoie E-M, Tremblay M, Houde L, Vézina H. Demogenetic study of three populations within a region with strong founder effects. Community Genet 2005;8:152-60.

8 Laberge A-M, Michaud J, Richter A, Lemyre E, Lambert M, Brais B, Mitchell GA. Population history and its impact on medical genetics in Quebec. Clin Genet 2005:68:287-301.

9 Moreau C, Vézina H, Labuda D. [Founder effects and genetic variability in Quebec]. Med Sci 2007;23:1008-13.

10 Lee N, Daly MJ, Delmonte T, Lander ES, Xu F, Hudson TJ, Mitchell GA, Morin CC, Robinson BH, Rioux JD. A genomewide linkage-disequilibrium scan localizes the Saguenay-Lac-Saint-Jean cytochrome oxidase deficiency to 2p16. Am J Hum Genet 2001;68:397-409.

11 Levesque S, Morin C, Guay S-P, Villeneuve J, Marquis P, Yik WY, Jiralerspong S, Bouchard L, Steinberg S, Hacia JG, Dewar K, Braverman NE. A founder mutation in the PEX6 gene is responsible for increased incidence of Zellweger syndrome in a French Canadian population. BMC Med Genet 2012;13:72

12 Mathieu J, Prévost C. Epidemiological surveillance of myotonic dystrophy type 1: a 25-year population-based study. Neuromuscul Disord 2012;22:974-9.

13 De Braekeleer M, Gauthier S. Autosomal recessive disorders in Saguenay-Lac-SaintJean (Quebec, Canada): a study of inbreeding. Ann Hum Genet 1996;60:51-6.

14 Vézina H, Tremblay M, Houde L. Mesures de l'apparentement biologique au Saguenay-Lac-St-Jean (Québec, Canada) à partir de reconstitutions généalogiques. Annales de démographie historique 2004;108:67-83.

15 Bouchard G. Information génétique et risque de stigmatisation collective. L'exemple du Saguenay-Lac-Saint-Jean. Med Sci 2004;20:933-5.
16 Tardif J, Pratte A, Laberge A-M. Experience of carrier couples identified through a population-based carrier screening pilot program for four founder autosomal recessive diseases in Saguenay-Lac-Saint-Jean. Prenat Diagn 2018;38:67-74.

17 Bouhlal Y, Amouri R, El Euch-Fayeche G, Hentati F. Autosomal recessive spastic ataxia of Charlevoix-Saguenay: an overview. Parkinsonism Relat Disord 2011;17:418-22.

18 Takiyama Y. Autosomal recessive spastic ataxia of Charlevoix-Saguenay. Neuropathology 2006;26:368-75.

19 Bouchard JP, Barbeau A, Bouchard R, Bouchard RW. Autosomal recessive spastic ataxia of Charlevoix-Saguenay. Can J Neurol Sci 1978;5:61-9.

20 Bouchard JP, Richter A, Mathieu J, Brunet D, Hudson TJ, Morgan K, Melançon SB. Autosomal recessive spastic ataxia of Charlevoix-Saguenay. Neuromuscul Disord 1998:8:474-9.

21 Ogawa T, Takiyama Y, Sakoe K, Mori K, Namekawa M, Shimazaki H, Nakano I, Nishizawa M. Identification of a sacs gene missense mutation in ARSACS. Neurology 2004;62:107-9.

22 Palmio J, Kärppä M, Baumann P, Penttilä S, Moilanen J, Udd B. Novel compound heterozygous mutation in SACS gene leads to a milder autosomal recessive spastic ataxia of Charlevoix-Saguenay, ARSACS, in a Finnish family. Clin Case Rep 2016:4:1151-6.

23 Agarwal PA, Ate-Upasani P, Ramprasad VL. Autosomal recessive spastic ataxia of Charlevoix-Saguenay (ARSACS) - first report of clinical and imaging features from India, and a novel SACS gene duplication. Mov Disord Clin Pract 2017;4:775-7.

24 Kuchay RAH, Mir YR, Zeng X, Hassan A, Musarrat J, Parwez I, Kernstock C, Traschütz A, Synofzik M. ARSACS as a worldwide disease: novel SACS mutations identified in a consanguineous family from the remote tribal Jammu and Kashmir region in India. Cerebellum 2019;18:807-12.

25 Engert JC, Bérubé P, Mercier J, Doré C, Lepage P, Ge B, Bouchard JP, Mathieu J, Melançon SB, Schalling M, Lander ES, Morgan K, Hudson TJ, Richter A. ARSACS, a spastic ataxia common in northeastern Québec, is caused by mutations in a new gene encoding an 11.5-kb ORF. Nat Genet 2000;24:120-5.

26 Thiffault I, Dicaire MJ, Tetreault M, Huang KN, Demers-Lamarche J, Bernard G, Duquette A, Larivière R, Gehring K, Montpetit A, McPherson PS, Richter A, Montermini L, Mercier J, Mitchell GA, Dupré N, Prévost C, Bouchard JP, Mathieu J, Brais B. Diversity of ARSACS mutations in French-Canadians. Can J Neurol Sci 2013:40:61-6.

27 Liu L, Li XB, Zi XH, Shen L, Hu ZM, Huang SX, Yu DL, Li HB, Xia K, Tang BS, Zhang RX, $\mathrm{Zh} \mathrm{H}$. A novel hemizygous sacs mutation identified by whole exome sequencing and SNP array analysis in a Chinese ARSACS patient. J Neurol Sci 2016;362:111-4.

28 Mercier J, Prévost C, Engert JC, Bouchard JP, Mathieu J, Richter A. Rapid detection of the sacsin mutations causing autosomal recessive spastic ataxia of CharlevoixSaguenay. Genet Test 2001;5:255-9.

29 Vermeer S, van de Warrenburg BP, Kamsteeg EJ, Brais B, Synofzik M. Arsacs. In: Adam MP, Ardinger HH, Pagon RA, Wallace SE, Bean LJH, Stephens K, Amemiya A, eds. GeneReviews((R)). Seattle (WA), 1993.

30 Dupré N, Howard HC, Mathieu J, Karpati G, Vanasse M, Bouchard J-P, Carpenter S, Rouleau GA. Hereditary motor and sensory neuropathy with agenesis of the corpus callosum. Ann Neurol 2003;54:9-18.

31 Larbrisseau A, Vanasse M, Brochu P, Jasmin G. The Andermann syndrome: agenesis of the corpus callosum associated with mental retardation and progressive sensorimotor neuronopathy. Can J Neurol Sci 1984;11:257-61.

32 Dupre N, Howard HC, Rouleau GA. Hereditary motor and sensory neuropathy with agenesis of the corpus callosum. In: Adam MP, Ardinger HH, Pagon RA, Wallace SE, Bean LJH, Stephens K, Amemiya A, eds. GeneReviews((R)). Seattle (WA), 1993.

33 Uyanik G, Elcioglu N, Penzien J, Gross C, Yilmaz Y, Olmez A, Demir E, Wahl D, Scheglmann K, Winner B, Bogdahn U, Topaloglu H, Hehr U, Winkler J. Novel truncating and missense mutations of the KCC 3 gene associated with Andermann syndrome. Neurology 2006;66:1044-8.

34 Morin C, Mitchell G, Larochelle J, Lambert M, Ogier H, Robinson BH, De Braekeleer M. Clinical, metabolic, and genetic aspects of cytochrome c oxidase deficiency in Saguenay-Lac-Saint-Jean. Am J Hum Genet 1993;53:488-96.

35 Debray F-G, Morin C, Janvier A, Villeneuve J, Maranda B, Laframboise R, Lacroix J, Decarie J-C, Robitaille Y, Lambert M, Robinson BH, Mitchell GA. LRPPRC mutations cause a phenotypically distinct form of Leigh syndrome with cytochrome c oxidase deficiency. J Med Genet 2011;48:183-9.

36 Mootha VK, Lepage P, Miller K, Bunkenborg J, Reich M, Hjerrild M, Delmonte T, Villeneuve A, Sladek R, Xu F, Mitchell GA, Morin C, Mann M, Hudson TJ, Robinson B, Rioux JD, Lander ES. Identification of a gene causing human cytochrome c oxidase deficiency by integrative genomics. Proc Natl Acad Sci U SA 2003;100:605-10.

37 Rackham O, Mercer TR, Filipovska A. The human mitochondrial transcriptome and the RNA-binding proteins that regulate its expression. Wiley Interdiscip Rev RNA 2012;3:675-95

38 Bergeron A, D'Astous M, Timm DE, Tanguay RM. Structural and functional analysis of missense mutations in fumarylacetoacetate hydrolase, the gene deficient in hereditary tyrosinemia type 1. J Biol Chem 2001;276:15225-31.

39 De Braekeleer M, Larochelle J. Genetic epidemiology of hereditary tyrosinemia in Quebec and in Saguenay-Lac-St-Jean. Am J Hum Genet 1990;47:302-7.

40 Mitchell G, Larochelle J, Lambert M, Michaud J, Grenier A, Ogier H, Gauthier M, Lacroix J, Vanasse M, Larbrisseau A, Paradis K, Weber A, Lefevre Y, Melançon 
S, Dallaire S. Neurologic crises in hereditary tyrosinemia. N Engl J Med 1990;322:432-7.

41 Larochelle J. Discovery of hereditary tyrosinemia in Saguenay- lac St-Jean. Adv Exp Med Biol 2017:959:3-8.

42 Chinsky JM, Singh R, Ficicioglu C, van Karnebeek CDM, Grompe M, Mitchell G, Waisbren SE, Gucsavas-Calikoglu M, Wasserstein MP, Coakley K, Scott CR. Diagnosis and treatment of tyrosinemia type I: a US and Canadian consensus group review and recommendations. Genet Med 2017;19. doi:10.1038/gim.2017.101. [Epub ahead of print: 03 Aug 2017].

43 Grompe M, St-Louis M, Demers SI, al-Dhalimy M, Leclerc B, Tanguay RM. A single mutation of the fumarylacetoacetate hydrolase gene in French Canadians with hereditary tyrosinemia type I. N Eng/ J Med 1994;331:353-7.

44 De Laet C, Munoz VT, Jaeken J, François B, Carton D, Sokal EM, Dan B, Goyens PJ. Neuropsychological outcome of NTBC-treated patients with tyrosinaemia type 1. Dev Med Child Neurol 2011:53:962-4.

45 Mitchell GA, Yang $\mathrm{H}$. Remaining challenges in the treatment of tyrosinemia from the clinician's viewpoint. Adv Exp Med Biol 2017:959:205-13.

46 Schiff M, Broue P, Chabrol B, De Laet C, Habes D, Mention K, Sarles J, Spraul A, Valayannopoulos V, Ogier de Baulny H, French-Belgian study group for HT-1. Heterogeneity of follow-up procedures in French and Belgian patients with treated hereditary tyrosinemia type 1: results of a questionnaire and proposed guidelines. J Inherit Metab Dis 2012;35:823-9.

47 Yin H, Xue W, Chen S, Bogorad RL, Benedetti E, Grompe M, Koteliansky V, Sharp PA, Jacks T, Anderson DG. Genome editing with Cas9 in adult mice corrects a disease mutation and phenotype. Nat Biotechnol 2014;32:551-3.

48 Giquère Y, Berthier M-T. Newborn screening for hereditary tyrosinemia type I in Québec: update. Adv Exp Med Biol 2017;959:139-46.

49 Romeo G, Devoto M, Galietta LJ. Why is the cystic fibrosis gene so frequent? Hum Genet 1989;84:1-5.

50 Boat TF, Cheng PW. Epithelial cell dysfunction in cystic fibrosis: implications for airways disease. Acta Paediatr Scand Supp/ 1989;363:25-30.

51 Daigneault J, Aubin G, Simard F, De Braekeleer M. Incidence of cystic fibrosis in Saguenay-Lac-St.-Jean (Quebec, Canada). Hum Biol 1992;64:115-9.

52 Rowntree RK, Harris A. The phenotypic consequences of CFTR mutations. Ann Hum Genet 2003:67:471-85.

53 Veit G, Avramescu RG, Chiang AN, Houck SA, Cai Z, Peters KW, Hong JS, Pollard HB, Guggino WB, Balch WE, Skach WR, Cutting GR, Frizzell RA, Sheppard DN, Cyr DM, Sorscher EJ, Brodsky JL, Lukacs GL. From CFTR biology toward combinatorial pharmacotherapy: expanded classification of cystic fibrosis mutations. Mol Biol Cell 2016;27:424-33.

54 Farrell P, Férec C, Macek M, Frischer T, Renner S, Riss K, Barton D, Repetto T, Tzetis M, Giteau K, Duno M, Rogers M, Levy H, Sahbatou M, Fichou Y, Le Maréchal C, Génin E. Estimating the age of $p$.(Phe508del) with family studies of geographically distinct European populations and the early spread of cystic fibrosis. Eur J Hum Genet 2018;26:1832-9.

55 Madore A-M, Prévost C, Dorfman R, Taylor C, Durie P, Zielenski J, Laprise C. Distribution of CFTR mutations in Saguenay- Lac-Saint-Jean: proposal of a panel of mutations for population screening. Genet Med 2008;10:201-6.

56 Rozen R, De Braekeleer M, Daigneault J, Ferreira-Rajabi L, Gerdes M, Lamoureux L, Aubin G, Simard F, Fujiwara TM, Morgan K. Cystic fibrosis mutations in French Canadians: three CFTR mutations are relatively frequent in a Quebec population with an elevated incidence of cystic fibrosis. Am J Med Genet 1992;42:360-4.

57 Sockrider MM, Ferkol TW. Twenty facts about cystic fibrosis. Am J Respir Crit Care Med 2017:196:P23-4.

58 Sears EH, Gartman EJ, Casserly BP. Treatment options for cystic fibrosis: state of the art and future perspectives. Rev Recent Clin Trials 2011;6:94-107.

59 Favia M, Gallo C, Guerra L, De Venuto D, Diana A, Polizzi AM, Montemurro P, Mariggiò MA, Leonetti G, Manca A, Casavola V, Conese M. Treatment of cystic fibrosis patients homozygous for F508de/ with lumacaftor-ivacaftor (Orkambi $\left.{ }^{\circledR}\right)$ restores defective CFTR channel function in circulating mononuclear cells. Int J Mol Sci 2020;21. doi:10.3390/iims21072398. [Epub ahead of print: 31 Mar 2020]

60 Hanrahan JW, Matthes E, Carlile G, Thomas DY. Corrector combination therapies for F508del-CFTR. Curr Opin Pharmacol 2017;34:105-11.

61 Ammer LS, Oussoren E, Muschol NM, Pohl S, Rubio-Gozalbo ME, Santer R, Stuecker R, Vettorazzi E, Breyer SR. Hip morphology in mucolipidosis type II. J Clin Med 2020;9. doi:10.3390/jcm9030728. [Epub ahead of print: 08 Mar 2020].

62 Sun A. Lysosomal storage disease overview. Ann Trans/ Med 2018;6.

63 Reitman ML, Varki A, Kornfeld S. Fibroblasts from patients with I-cell disease and pseudo-Hurler polydystrophy are deficient in uridine $5^{\prime}$-diphosphate- $\mathrm{N}$ acetylglucosamine: glycoprotein $\mathrm{N}$-acetylglucosaminylphosphotransferase activity. J Clin Invest 1981:67:1574-9.

64 Plante M, Claveau S, Lepage P, Lavoie E-M, Brunet S, Roquis D, Morin C, Vézina H, Laprise C. Mucolipidosis II: a single causal mutation in the N-acetylglucosamine-1 phosphotransferase gene (GNPTAB) in a French Canadian founder population. Clin Genet 2008;73:236-44.

65 Bargal R, Zeigler M, Abu-Libdeh B, Zuri V, Mandel H, Ben Neriah Z, Stewart F, Elcioglu N, Hindi T, Le Merrer M, Bach G, Raas-Rothschild A. When mucolipidosis
III meets mucolipidosis II: GNPTA gene mutations in 24 patients. Mol Genet Metab 2006:88:359-63.

66 Kudo M, Brem MS, Canfield WM. Mucolipidosis II (I-cell disease) and mucolipidosis Illa (classical pseudo-Hurler polydystrophy) are caused by mutations in the GIcNAc-phosphotransferase alpha/beta-subunits precursor gene. Am J Hum Genet 2006:78:451-63.

67 Sabbia T, Bovone S, Camera A, Balbi P, Camera G. [Gingival hypertrophy in I-cell disease (mucolipidosis II). A report of 2 nonfamilial cases. II]. Minerva Stomatol 1993;42:63-7.

68 Mahfouz AKM, George G. Anesthesia for gingivectomy and dental extractions in a child with I-cell disease — a case report. Middle East J Anaesthesiol 2011;21:121-4.

69 Leroy JG, Sillence D, Wood T, Barnes J, Lebel RR, Friez MJ, Stevenson RE, Steet R, Cathey SS. A novel intermediate mucolipidosis $\|/ /\| \alpha \beta$ caused by GNPTAB mutation in the cytosolic N-terminal domain. Eur J Hum Genet 2014;22:594-601.

70 Kim CJ.Vitamin D dependent rickets type I. Korean J Pediatr 2011;54:51-4.

71 Delvin EE, Glorieux FH. Serum 1,25-dihydroxyvitamin D concentration in hypophosphatemic vitamin D-resistant rickets. Calcif Tissue Int 1981:33:173-5.

72 Labuda M, Morgan K, Glorieux FH. Mapping autosomal recessive vitamin D dependency type I to chromosome 12q14 by linkage analysis. Am J Hum Genet 1990;47:28-36

73 Fraser D, Kooh SW, Kind HP, Holick MF, Tanaka Y, DeLuca HF. Pathogenesis of hereditary vitamin-D-dependent rickets. An inborn error of vitamin $D$ metabolism involving defective conversion of 25-hydroxyvitamin D to 1 alpha, 25dihydroxyvitamin D. N Engl J Med 1973;289:817-22.

74 Dursun F, Özgürhan G, Kırmızıbekmez H, Keskin E, Hacıhamdioğlu B. Genetic and clinical characteristics of patients with vitamin D dependent rickets type 1A. J Clin Res Pediatr Endocrinol 2019;11:34-40

75 Scriver CR. Vitamin D dependency. Pediatrics 1970:45:361-3.

76 Yoshida T, Monkawa T, Tenenhouse HS, Goodyer P, Shinki T, Suda T, Wakino S, Hayashi M, Saruta T. Two novel 1alpha-hydroxylase mutations in French-Canadians with vitamin D dependency rickets type I1. Kidney Int 1998;54:1437-43.

77 Wang JT, Lin CJ, Burridge SM, Fu GK, Labuda M, Portale AA, Miller WL. Genetics of vitamin D 1alpha-hydroxylase deficiency in 17 families. Am J Hum Genet 1998;63:1694-702.

78 Lung BE, Mowery ML, Komatsu DEE. Calcitriol. Treasure Island (FL): StatPearls, 2020.

79 Hegele RA, Borén J, Ginsberg HN, Arca M, Averna M, Binder CJ, Calabresi L, Chapman MJ, Cuchel M, von Eckardstein A, Frikke-Schmidt R, Gaudet D, Hovingh GK, Kronenberg F, Lütjohann D, Parhofer KG, Raal FJ, Ray KK, Remaley AT, Stock JK, Stroes ES, Tokgözoğlu L, Catapano AL. Rare dyslipidaemias, from phenotype to genotype to management: a European Atherosclerosis Society Task Force consensus statement. Lancet Diabetes Endocrinol 2020;8:50-67.

80 Mahley RW, Rall SC. Type III hyperlipoproteinemia (Dysbetalipoproteinemia): the role of apolipoprotein E in normal and abnormal lipoprotein metabolism. In: Scriver CR, ed. The metabolic and molecular bases of inherited disease. 8. New York: McGrawHill Professionnal, 2001: Il. 6338.

81 Gagné C, Gaudet D. Les dyslipoprotéinémies : L'approche clinique. 3e édition. Lipimed Communications, 2007.

82 Weisgraber KH, Newhouse YM, Taylor JM, Tuan B, Nestruck AC, Davignon J, Mahley RW. Apolipoprotein E2(Arg158----Cys) frequency in a hyperlipidemic FrenchCanadian population of apolipoprotein E2/2 subjects. Determination by synthetic oligonucleotide probes. Arteriosclerosis 1989;9:50-7.

83 Moorjani S, Morissette J, Laberge C. Apoe polymorphism in Quebec population. Clin and Invest Med 1987;10

84 Perron P, Brisson D, Santuré M, Blackburn P, Bergeron J, Vohl MC, Després JP, Gaudet D. Apolipoprotein E and lipoprotein lipase gene polymorphisms interaction on the atherogenic combined expression of hypertriglyceridemia and hyperapobetalipoproteinemia phenotypes. J Endocrinol Invest 2007;30:551-7.

85 Hegele RA, Berberich AJ, Ban MR, Wang J, Digenio A, Alexander VJ, D'Erasmo L, Arca M, Jones A, Bruckert E, Stroes ES, Bergeron J, Civeira F, Witztum JL, Gaudet D. Clinical and biochemical features of different molecular etiologies of familial chylomicronemia. J Clin Lipidol 2018;12:920-7.

86 Gagné C, Gaudet D. [Dyslipoproteinemias in Quebec: primary deficit in lipoprotein lipase and familial hypercholesterolemia]. Union Med Can 1995;124:61-7.

87 Normand T, Bergeron J, Fernandez-Margallo T, Bharucha A, Ven Murthy MR, Julien P, Gagné C, Dionne C, De Braekeleer M, Ma R, Murthy V. Geographic distribution and genealogy of mutation 207 of the lipoprotein lipase gene in the French Canadian population of Québec. Hum Genet 1992;89:671-5.

88 Dionne C, Gagné C, Julien P, Murthy MR, Lambert M, Roederer G, Davignon J, Hayden MR, Lupien PJ, de Braekeleer M. Genetic epidemiology of lipoprotein lipase deficiency in Saguenay-Lac-St-Jean (Québec, Canada). Ann Genet 1992;35:89-92.

89 Gaudet D, Brisson D, Tremblay K, Alexander VJ, Singleton W, Hughes SG, Geary RS, Baker BF, Graham MJ, Crooke RM, Witztum JL. Targeting APOC3 in the familial chylomicronemia syndrome. N Engl J Med 2014;371:2200-6.

90 Gaudet D, Alexander VJ, Baker BF, Brisson D, Tremblay K, Singleton W, Geary RS, Hughes SG, Viney NJ, Graham MJ, Crooke RM, Witztum JL, Brunzell JD, Kastelein JJP. Antisense inhibition of apolipoprotein C-III in patients with hypertriglyceridemia. N Engl J Med 2015;373:438-47. 
91 Witztum JL, Gaudet D, Freedman SD, Alexander VJ, Digenio A, Williams KR, Yang Q, Hughes SG, Geary RS, Arca M, Stroes ESG, Bergeron J, Soran H, Civeira F, Hemphill L, Tsimikas S, Blom DJ, O'Dea L, Bruckert E. Volanesorsen and triglyceride levels in familial chylomicronemia syndrome. N Engl J Med 2019;381:531-42.

92 Gaudet D, Méthot J, Déry S, Brisson D, Essiembre C, Tremblay G, Tremblay K, de Wal J, Twisk J, van den Bulk N, Sier-Ferreira V, van Deventer S. Efficacy and long-term safety of alipogene tiparvovec (AAV1-LPLS447X) gene therapy for lipoprotein lipase deficiency: an open-label trial. Gene Ther 2013;20:361-9.

93 Gaudet D, Stroes ES, Méthot J, Brisson D, Tremblay K, Bernelot Moens SJ, lotti G, Rastelletti I, Ardigo D, Meyer C, Andersen M, Ruszniewski P, Deakin M, Bruno MJ, Bruno MJ. Long-term retrospective analysis of gene therapy with alipogene tiparvovec and its effect on lipoprotein lipase deficiency-induced pancreatitis. Hum Gene Ther 2016:27:916-25.

94 Gaudet D, Karwatowska-Prokopczuk E, Baum SJ, Hurh E, Kingsbury J, Bartlett VJ, Figueroa AL, Piscitelli P, Singleton W, Witztum JL, Geary RS, Tsimikas S, O'Dea LSL, Vupanorsen Study Investigators. Vupanorsen, an $\mathrm{N}$-acetyl galactosamine-conjugated antisense drug to ANGPTL3 mRNA, lowers triglycerides and atherogenic lipoproteins in patients with diabetes, hepatic steatosis, and hypertriglyceridaemia. Eur Heart J 2020:41:3936-45.

95 Dron JS, Wang J, Cao H, McIntyre AD, lacocca MA, Menard JR, Movsesyan I, Malloy MJ, Pullinger CR, Kane JP, Hegele RA. Severe hypertriglyceridemia is primarily polygenic. J Clin Lipidol 2019;13:80-8.

96 Turner C, Hilton-Jones D. The myotonic dystrophies: diagnosis and management. J Neurol Neurosurg Psychiatry 2010;81:358-67.

97 Gagnon C, Chouinard MC, Laberge L, Veillette S, Bégin P, Breton R, Jean S, Brisson D, Gaudet D, Mathieu J, DMI Expert Panel. Health supervision and anticipatory guidance in adult myotonic dystrophy type 1. Neuromuscul Disord 2010;20:847-51.

98 Harper PS, van Engelen BGM, Eymard B, Rogers M, Wilcox D. 99th ENMC International workshop: myotonic dystrophy: present management, future therapy. 9-11 November 2001, Naarden, the Netherlands. Neuromuscul Disord 2002;12:596-9.

99 Yotova V, Labuda D, Zietkiewicz E, Gehl D, Lovell A, Lefebvre J-F, Bourgeois S, Lemieux-Blanchard E, Labuda M, Vézina H, Houde L, Tremblay M, Toupance B, Heyer E, Hudson TJ, Laberge C. Anatomy of a founder effect: myotonic dystrophy in northeastern Quebec. Hum Genet 2005;117:177-87.

100 Shaw DJ, Harper PS. Myotonic dystrophy: advances in molecular genetics. Neuromuscul Disord 1992;2:241-3.

101 Roussel M-P, Morin M, Gagnon C, Duchesne E. What is known about the effects of exercise or training to reduce skeletal muscle impairments of patients with myotonic dystrophy type 1? A scoping review. BMC Musculoskelet Disord 2019;20:101.

102 Smith CA, Gutmann L. Myotonic dystrophy type 1 management and therapeutics. Curr Treat Options Neurol 2016;18:52.

103 Roussel M-P, Morin M, Girardin M, Fortin A-M, Leone M, Mathieu J, Gagnon C, Duchesne E. Training program-induced skeletal muscle adaptations in two men with myotonic dystrophy type 1. BMC Res Notes 2019;12:526.

104 Santos RD, Gidding SS, Hegele RA, Cuchel MA, Barter PJ, Watts GF, Baum SJ, Catapano AL, Chapman MJ, Defesche JC, Folco E, Freiberger T, Genest J, Hovingh GK, Harada-Shiba M, Humphries SE, Jackson AS, Mata P, Moriarty PM, Raa FJ, Al-Rasadi K, Ray KK, Reiner Z, Sijbrands EJG, Yamashita S, International Atherosclerosis Society Severe Familial Hypercholesterolemia Panel. Defining severe familial hypercholesterolaemia and the implications for clinical management: a consensus statement from the International Atherosclerosis Society Severe Familial Hypercholesterolemia Panel. Lancet Diabetes Endocrinol 2016;4:850-61.

105 Berberich AJ, Hegele RA. The complex molecular genetics of familial hypercholesterolaemia. Nat Rev Cardiol 2019;16:9-20.

106 Nordestgaard BG, Chapman MJ, Humphries SE, Ginsberg HN, Masana L, Descamps OS, Wiklund O, Hegele RA, Raal FJ, Defesche JC, Wiegman A, Santos RD, Watts GF, Parhofer KG, Hovingh GK, Kovanen PT, Boileau C, Averna M, Borén J, Bruckert E, Catapano AL, Kuivenhoven JA, Pajukanta P, Ray K, Stalenhoef AFH, Stroes E, Taskinen M-R, Tybjærg-Hansen A, European Atherosclerosis Society Consensus Panel. Familial hypercholesterolaemia is underdiagnosed and undertreated in the general population: guidance for clinicians to prevent coronary heart disease: consensus statement of the European Atherosclerosis Society. Eur Heart J 2013;34:3478-90.

107 Moorjani S, Roy M, Gagné C, Davignon J, Brun D, Toussaint M, Lambert M, Campeau L, Blaichman S, Lupien P. Homozygous familial hypercholesterolemia among French Canadians in Québec Province. Arteriosclerosis 1989:9:211-6.

108 Gaudet D, Tremblay G, Perron P, Gagné C, Ouadahi Y, Moorjani S. [Familial hypercholesterolemia in eastern Quebec: a public health problem? The experience of the hyperlipidemia clinic of Chicoutimi]. Union Med Can 1995;124:54-60.

109 Vohl MC, Moorjani S, Roy M, Gaudet D, Torres AL, Minnich A, Gagné C, Tremblay G, Lambert M, Bergeron J, Couture P, Perron P, Blaichman S, Brun LD, Davignon J, Lupien PJ, Després JP. Geographic distribution of French-Canadian low-density lipoprotein receptor gene mutations in the Province of Quebec. Clin Genet 1997:52:1-6.

110 Alothman L, Zawadka M, Aljenedil S, Kajil M, Bewick D, Gaudet D, Hegele RA, Lonn E, Ngui D, Ruel I, Tsigoulis M, Singh N, Genest J, Gupta M. Prediction of familial hypercholesterolemia in patients at high atherosclerotic cardiovascular disease risk using a recently validated algorithm. CJC Open 2019;1:190-7.
111 Ruel I, Brisson D, Aljenedil S, Awan Z, Baass A, Bélanger A, Bergeron J, Bewick D, Brophy JM, Brunham LR, Couture P, Dufour R, Francis GA, Frohlich J, Gagné C, Gaudet D, Grégoire JC, Gupta M, Hegele RA, Mancini GBJ, McCrindle BW, Pang J, Raggi P, Tu JV, Watts GF, Genest J. Simplified Canadian definition for familial hypercholesterolemia. Can J Cardiol 2018;34:1210-4.

112 Besseling J, Reitsma JB, Gaudet D, Brisson D, Kastelein JJP, Hovingh GK, Hutten BA. Selection of individuals for genetic testing for familial hypercholesterolaemia: development and external validation of a prediction model for the presence of a mutation causing familial hypercholesterolaemia. Eur Heart J 2017;38:565-73.

113 Brunham LR, Ruel I, Aljenedil S, Rivière J-B, Baass A, Tu JV, Mancini GBJ, Raggi P, Gupta M, Couture P, Pearson GJ, Bergeron J, Francis GA, McCrindle BW, Morrison K, St-Pierre J, Henderson M, Hegele RA, Genest J, Goguen J, Gaudet D, Paré G, Romney J, Ransom T, Bernard S, Katz P, Joy TR, Bewick D, Brophy J. Canadian cardiovascular Society position statement on familial hypercholesterolemia: update 2018. Can J Cardiol 2018;34:1553-63

114 Kusters DM, Avis HJ, de Groot E, Wijburg FA, Kastelein JJP, Wiegman A, Hutten $B A$. Ten-year follow-up after initiation of statin therapy in children with familial hypercholesterolemia. JAMA 2014;312:1055-7.

115 Luirink IK, Wiegman A, Kusters DM, Hof MH, Groothoff JW, de Groot E, Kastelein JJP, Hutten BA. 20-Year follow-up of statins in children with familial hypercholesterolemia. N Eng/ J Med 2019;381:1547-56.

116 Raal FJ, Stein EA, Dufour R, Turner T, Civeira F, Burgess L, Langslet G, Scott R, Olsson AG, Sullivan D, Hovingh GK, Cariou B, Gouni-Berthold I, Somaratne R, Bridges I, Scott R, Wasserman SM, Gaudet D, RUTHERFORD-2 Investigators. PCSK9 inhibition with evolocumab (AMG 145) in heterozygous familial hypercholesterolaemia (RUTHERFORD-2): a randomised, double-blind, placebo-controlled trial. Lancet 2015:385:331-40.

117 Dufour R, Bergeron J, Gaudet D, Weiss R, Hovingh GK, Qing Z, Yang F, Andisik M, Torri A, Pordy R, Gipe DA. Open-label therapy with alirocumab in patients with heterozygous familial hypercholesterolemia: results from three years of treatment. Int J Cardiol 2017;228:754-60.

118 Khoury E, Brisson D, Gaudet D. Preclinical discovery and development of evolocumab for the treatment of hypercholesterolemia. Expert Opin Drug Discov 2020:15:403-14

119 Ray KK, Landmesser U, Leiter LA, Kallend D, Dufour R, Karakas M, Hall T, Troquay RPT, Turner T, Visseren FLJ, Wijngaard P, Wright RS, Kastelein JJP. Inclisiran in patients at high cardiovascular risk with elevated LDL cholesterol. N Eng/ J Med 2017:376:1430-40.

120 Gaudet D, Langslet G, Gidding SS, Luirink IK, Ruzza A, Kurtz C, Lu C, Somaratne R, Raal FJ, Wiegman A. Efficacy, safety, and tolerability of evolocumab in pediatric patients with heterozygous familial hypercholesterolemia: rationale and design of the HAUSER-RCT study. J Clin Lipidol 2018;12:1199-207.

121 Santos RD, Ruzza A, Hovingh GK, Wiegman A, Mach F, Kurtz CE, Hamer A, Bridges I, Bartuli A, Bergeron J, Szamosi T, Santra S, Stefanutti C, Descamps OS, Greber-Platzer S, Luirink I, Kastelein JJP, Gaudet D, HAUSER-RCT Investigators. Evolocumab in pediatric heterozygous familial hypercholesterolemia. N Engl J Med 2020;383:1317-27.

122 Gaudet D, Ruzza A, Santos RD. Evolocumab in pediatric heterozygous familial hypercholesterolemia. reply. N Eng/ J Med 2021;384:84-5.

123 Blom DJ, Averna MR, Meagher EA, du Toit Theron H, Sirtori CR, Hegele RA, Shah PK, Gaudet D, Stefanutti C, Vigna GB, Larrey D, Bloedon LT, Foulds P, Rader DJ, Cuchel M, Theron duT, Rader DJ, Cuchel M, Theron duT. Long-term efficacy and safety of the microsomal triglyceride transfer protein inhibitor lomitapide in patients with homozygous familial hypercholesterolemia. Circulation 2017:136:332-5.

124 Khoury E, Brisson D, Roy N, Tremblay G, Gaudet D. Review of the long-term safety of lomitapide: a microsomal triglycerides transfer protein inhibitor for treating homozygous familial hypercholesterolemia. Expert Opin Drug Saf 2019;18:403-14.

125 Aljenedil S, Alothman L, Bélanger AM, Brown L, Lahijanian Z, Bergeron J, Couture P, Baass A, Ruel I, Brisson D, Khoury E, Gaudet D, Genest J. Lomitapide for treatment of homozygous familial hypercholesterolemia: the Québec experience. Atherosclerosis 2020;310:54-63

126 Gaudet D, Gipe DA, Pordy R, Ahmad Z, Cuchel M, Shah PK, Chyu K-Y, Sasiela WJ, Chan K-C, Brisson D, Khoury E, Banerjee P, Gusarova V, Gromada J, Stahl N, Yancopoulos GD, Hovingh GK. ANGPTL3 inhibition in homozygous familial hypercholesterolemia. N Engl J Med 2017;377:296-7.

127 Raal FJ, Rosenson RS, Reeskamp LF, Hovingh GK, Kastelein JJP, Rubba P, Ali S, Banerjee P, Chan K-C, Gipe DA, Khilla N, Pordy R, Weinreich DM, Yancopoulos GD, Zhang Y, Gaudet D, ELIPSE HoFH Investigators. Evinacumab for homozygous familial hypercholesterolemia. N Engl J Med 2020;383:711-20.

128 Rosenson RS, Burgess LJ, Ebenbichler CF, Baum SJ, Stroes ESG, Ali S, Khilla N, Hamlin R, Pordy R, Dong Y, Son V, Gaudet D. Evinacumab in patients with refractory hypercholesterolemia. N Engl J Med 2020;383:2307-19.

129 Kalatzis V, Cherqui S, Antignac C, Gasnier B. Cystinosin, the protein defective in cystinosis, is a H(+)-driven lysosomal cystine transporter. Embo J 2001;20:5940-9.

130 Midgley JP, El-Kares R, Mathieu F, Goodyer P. Natural history of adolescent-onset cystinosis. Pediatr Nephrol 2011;26:1335-7. 
131 McGowan-Jordan J, Stoddard K, Podolsky L, Orrbine E, McLaine P, Town M, Goodyer P, MacKenzie A, Heick H. Molecular analysis of cystinosis: probable Irish origin of the most common French Canadian mutation. Eur J Hum Genet 1999;7:671-8.

132 Gahl WA, Thoene JG, Schneider JA. Cystinosis. N Engl J Med 2002;347:111-21.

133 Emma F, Nesterova G, Langman C, Labbé A, Cherqui S, Goodyer P, Janssen MC, Greco M, Topaloglu R, Elenberg E, Dohil R, Trauner D, Antignac C, Cochat P, Kaskel F, Servais A, Wühl E, Niaudet P, Van't Hoff W, Gahl W, Levtchenko E. Nephropathic cystinosis: an international consensus document. Nephrol Dial Transplant 2014;29:iv87-94.

134 Bois E, Feingold J, Frenay P, Briard ML. Infantile cystinosis in France: genetics, incidence, geographic distribution. J Med Genet 1976;13:434-8.

135 Town M, Jean G, Cherqui S, Attard M, Forestier L, Whitmore SA, Callen DF, Gribouval O, Broyer M, Bates GP, van't Hoff W, Antignac C. A novel gene encoding an integral membrane protein is mutated in nephropathic cystinosis. Nat Genet 1998;18:319-24.

136 Thoene JG, Oshima RG, Crawhall JC, Olson DL, Schneider JA. Cystinosis. Intracellular cystine depletion by aminothiols in vitro and in vivo. J Clin Invest 1976;58:180-9.

137 Elmonem MA, Veys KR, Soliman NA, van Dyck M, van den Heuvel LP, Levtchenko E. Cystinosis: a review. Orphanet J Rare Dis 2016;11:47.

138 Gahl WA, Reed GF, Thoene JG, Schulman JD, Rizzo WB, Jonas AJ, Denman DW, Schlesselman JJ, Corden BJ, Schneider JA. Cysteamine therapy for children with nephropathic cystinosis. N Engl J Med 1987;316:971-7.

139 Ariceta G, Lara E, Camacho JA, Oppenheimer F, Vara J, Santos F, Muñoz MA, Cantarell C, Gil Calvo M, Romero R, Valenciano B, García-Nieto V, Sanahuja MJ, Crespo J, Justa ML, Urisarri A, Bueno A, Bravo J, Llamas F, Jiménez Del Cerro LA Llamas F, Jiménez Del Cerro LA. Cysteamine (Cystagon $®$ ) adherence in patients with cystinosis in Spain: successful in children and a challenge in adolescents and adults. Nephrol Dial Transplant 2015;30:475-80.

140 Brasell EJ, Chu LL, Akpa MM, Eshkar-Oren I, Alroy I, Corsini R, Gilfix BM, Yamanaka Y, Huertas P, Goodyer P. The novel aminoglycoside, ELX-02, permits CTNSW138X translational read-through and restores lysosomal cystine efflux in cystinosis. PLOS One 2019;14:e0223954.

141 Steinberg SJ, Dodt G, Raymond GV, Braverman NE, Moser AB, Moser HW. Peroxisome biogenesis disorders. Biochim Biophys Acta 2006;1763:1733-48.

142 Havali C, Dorum S, Akbaş Y, Görükmez O, Hirfanoglu T. Two different missense mutations of PEX genes in two similar patients with severe Zellweger syndrome: an argument on the genotype-phenotype correlation. J Pediatr Endocrinol Metab 2020;33:437-41.

143 Ebberink MS, Mooijer PAW, Gootjes J, Koster J, Wanders RJA, Waterham HR. Genetic classification and mutational spectrum of more than 600 patients with a Zellweger syndrome spectrum disorder. Hum Mutat 2011;32:59-69.

144 Steinberg S, Chen L, Wei L, Moser A, Moser H, Cutting G, Braverman N. The PEX Gene Screen: molecular diagnosis of peroxisome biogenesis disorders in the Zellweger syndrome spectrum. Mol Genet Metab 2004;83:252-63.
145 Matsumoto N, Tamura S, Moser A, Moser HW, Braverman N, Suzuki Y, Shimozawa $\mathrm{N}$, Kondo N, Fujiki Y. The peroxin Pex6p gene is impaired in peroxisomal biogenesis disorders of complementation group 6. J Hum Genet 2001;46:273-7.

146 Protonotarios N, Tsatsopoulou A, Patsourakos P, Alexopoulos D, Gezerlis P, Simitsis S, Scampardonis G. Cardiac abnormalities in familial palmoplantar keratosis. Br Heart J 1986;56:321-6.

147 Protonotarios N, Tsatsopoulou A. Naxos disease: cardiocutaneous syndrome due to cell adhesion defect. Orphanet J Rare Dis 2006;1:4.

148 Marino TC, Maranda B, Leblanc J, Pratte A, Barabas M, Dupéré A, Lévesque S. Novel founder mutation in French-Canadian families with Naxos disease. Clin Genet 2017; $92: 451-3$

149 McNally EM, MacLeod H. Therapy insight: cardiovascular complications associated with muscular dystrophies. Nat Clin Pract Cardiovasc Med 2005;2:301-8.

150 Pfendner EG, Sadowski SG, Uitto J. Epidermolysis bullosa simplex: recurrent and de novo mutations in the KRT5 and KRT14 genes, phenotype/genotype correlations, and implications for genetic counseling and prenatal diagnosis. J Invest Dermatol 2005;125:239-43.

151 Bolling MC, Lemmink HH, Jansen GHL, Jonkman MF. Mutations in KRT5 and KRT14 cause epidermolysis bullosa simplex in $75 \%$ of the patients. $\mathrm{Br} J$ Dermatol 2011;164:no-44.

152 Sprecher E. Epidermolysis bullosa simplex. Dermatol Clin 2010;28:23-32.

153 Bchetnia M, Tremblay M-L, Leclerc G, Dupérée A, Powell J, McCuaig C, Morin C, Legendre-Guillemin V, Laprise C. Expression signature of epidermolysis bullosa simplex. Hum Genet 2012;131:393-406.

154 Bruckner-Tuderman L. Newer treatment modalities in epidermolysis bullosa. Indian Dermatol Online J 2019;10:244-50.

155 Vigneault A, Brisson D, Bélanger C, Gaudet D. Community genetics in eastern Québec: the experience of the Corporation for Research and Action on Hereditary Diseases. Community Genet 2000;3:151-5.

156 Gaudet D, Hudson TJ, Laberge C. From community genetics to community genomics: the Quebec experience. Public Health Genomics 2000;3:134-40.

157 Perron M, Veillette S. Social issues of molecular biology applications in communities: focussing on social representations and the public's perceptions. Public Health Genomics 2000;3:109-11.

158 Pouliot S, Rousseau J. Rapport d'évaluation du Projet-pilote d'offre de tests de porteur pour quatre maladies héréditaires récessives au Saguenay-Lac-Saint-Jean. In: Rapport de I'Institut national de santé publique du Québec (INSPQ). N de publication, 2013.

159 Pouliot S, Rousseau J. Rapport d'évaluation du Projet-pilote d'offre de tests de porteur pour quatre maladies héréditaires récessives au Saguenay-Lac-Saint-Jean. In: Rapport de I'Institut national de santé publique du Québec (INSPQ). № de publication, 2014.

160 Dionne C, Gagné C, Julien P, Murthy MR, Lambert M, Roederer G, Davignon J, Hayden MR, Lupien PJ, de Braekeleer M. Genetic epidemiology of lipoprotein lipase deficiency in Saguenay-Lac-St-Jean (Quebec, Canada). Ann Genet 1992;35:89-92. 